\title{
Gaseous products and secondary organic aerosol formation during long term oxidation of isoprene and methacrolein
}

\author{
L. Brégonzio-Rozier ${ }^{1}$, F. Siekmann ${ }^{2}$, C. Giorio ${ }^{3,4}$, E. Pangui ${ }^{1}$, S. B. Morales ${ }^{1}$, B. Temime-Roussel ${ }^{2}$, A. Gratien ${ }^{1}$, \\ V. Michoud ${ }^{1}$, S. Ravier ${ }^{2}$, M. Cazaunau ${ }^{1}$, A. Tapparo ${ }^{4}$, A. Monod ${ }^{2}$, and J.-F. Doussin ${ }^{1}$ \\ ${ }^{1}$ Laboratoire Interuniversitaire des Systèmes Atmosphériques (LISA), UMR7583, CNRS, Université Paris-Est-Créteil \\ (UPEC) et Université Paris Diderot (UPD), Institut Pierre Simon Laplace (IPSL), Créteil, France \\ ${ }^{2}$ Aix-Marseille Université, CNRS, LCE FRE 3416, 13331, Marseille, France \\ ${ }^{3}$ Department of Chemistry, University of Cambridge, Cambridge CB2 1EW, UK \\ ${ }^{4}$ Dipartimento di Scienze Chimiche, Università degli Studi di Padova, Padova, 35131, Italy \\ Correspondence to: L. Brégonzio-Rozier (lola.bregonzio@lisa.u-pec.fr)
}

Received: 20 July 2014 - Published in Atmos. Chem. Phys. Discuss.: 2 September 2014

Revised: 13 January 2015 - Accepted: 13 February 2015 - Published: 17 March 2015

\begin{abstract}
First- and higher order-generation products formed from the oxidation of isoprene and methacrolein with $\mathrm{OH}$ radicals in the presence of $\mathrm{NO}_{\mathrm{x}}$ have been studied in a simulation chamber. Significant oxidation rates have been maintained for up to $7 \mathrm{~h}$, allowing the study of highly oxidized products. Gas-phase product distribution and yields were obtained, and show good agreement with previous studies. Secondary organic aerosol (SOA) formation has also been investigated. SOA mass yields from previous studies show large discrepancies. The mass yields obtained here were consistent with the lowest values found in the literature, and more specifically in agreement with studies carried out with natural light or artificial lamps with emission similar to the solar spectrum. Differences in light source are therefore proposed to explain partially the discrepancies observed between different studies in the literature for both isopreneand methacrolein-SOA mass yields. There is a high degree of similarity between the SOA mass spectra from isoprene and methacrolein photooxidation, thus strengthening the importance of the role of methacrolein in SOA formation from isoprene photooxidation under our experimental conditions (i.e., presence of $\mathrm{NO}_{\mathrm{x}}$ and long term oxidation). According to our results, SOA mass yields from both isoprene and methacrolein in the atmosphere could be lower than suggested by most of the current chamber studies.
\end{abstract}

\section{Introduction}

Isoprene (2-methyl-1,3-butadiene) is a biogenic volatile organic compound (VOC) emitted by vegetation. It is one of the most abundant non-methane hydrocarbons emitted into the troposphere, with annual global emissions of 440 to $660 \mathrm{TgC}$ (Guenther et al., 2006). As a diene, isoprene is highly reactive in the atmosphere, resulting in low atmospheric lifetimes due to its reaction with atmospheric oxidants, especially the hydroxyl radical $(\mathrm{OH})$, with a lifetime of $1.7 \mathrm{~h}$ (Karl et al., 2006). Because of its large emission rates and high reactivity, isoprene can have a strong influence on tropospheric photochemistry on the local, regional and global scales. The OHinitiated oxidation of isoprene leads to the production of firstgeneration oxidation compounds, i.e., first stable products which result from the initial $\mathrm{OH}$ attack on isoprene and do not involve additional attack by atmospheric oxidants $(\mathrm{OH}$, $\mathrm{O}_{3}$ or $\mathrm{NO}_{3}$ ). The major primary products, in the presence of nitrogen oxides $\left(\mathrm{NO}_{\mathrm{x}}=\mathrm{NO}+\mathrm{NO}_{2}\right)$, are methyl vinyl ketone (MVK), methacrolein (MACR), and formaldehyde (HCHO) (Miyoshi et al., 1994; Paulson and Seinfeld, 1992; Sprengnether et al., 2002; Tuazon and Atkinson, 1990a). Isoprene photooxidation in the presence of sufficient $\mathrm{NO}_{\mathrm{x}}$ is also known to result in the production of significant quantities of ozone on regional scales, in rural as well as in urban areas during summer (Biesenthal et al., 1997; Starn et al., 1998; Wiedinmyer et al., 2001). 
For years, it was considered that, because of the high volatility of first-generation products, secondary organic aerosol (SOA) formation from isoprene photooxidation in the presence of $\mathrm{NO}_{\mathrm{x}}$ was insignificant in the troposphere (Pandis et al., 1991). However, in the early 2000s, detailed analysis of natural aerosols from the Amazonian rain forest (Claeys et al., 2004) showed significant amounts of two diastereoisomeric 2-methyltetrols (2-methylerythritol and 2methylthreitol). These compounds bear the isoprene skeleton, and their biogenic sources are not primary. Following this discovery, SOA formation from isoprene has been reconsidered: field observations (Edney et al., 2005; Ion et al., 2005; Kourtchev et al., 2005) and laboratory chamber studies (Boge et al., 2006; Edney et al., 2005; Kroll et al., 2005) confirmed the ability of isoprene (or its oxidation products) to contribute significantly to atmospheric SOA. In fact, even if isoprene leads to small SOA yields (few percent or less), the global contribution of isoprene to the total particulate organic matter could be important considering its large emissions on the global scale. Because organic matter (mostly with secondary origin) accounts for a large, and often dominant, fraction (between 20 and $90 \%$ ) of fine particulate mass in the atmosphere (Kanakidou et al., 2005; Zhang et al., 2007), it is important to fully understand the SOA formation processes from isoprene oxidation, and especially the impact of the experimental conditions on SOA yields.

Laboratory chamber studies investigated the dependence of isoprene-SOA yields on $\mathrm{NO}_{\mathrm{x}}$ levels (Kroll et al., 2006; Surratt et al., 2006). They showed that SOA yields are higher in the absence of $\mathrm{NO}_{\mathrm{x}}$, thus suggesting an important role of peroxy radical chemistry $\left(\mathrm{RO}_{2}\right)$. When $\mathrm{RO}_{2}$ chemistry is dominated by the $\mathrm{RO}_{2}+\mathrm{NO}$ reaction, small alkoxy radicals (RO, which tend to fragment), and organic nitrates are formed and are likely sufficiently volatile to remain in the gas phase. On the contrary, in the absence of $\mathrm{NO}_{\mathrm{x}}(<1 \mathrm{ppb})$, $\mathrm{RO}_{2}$ radicals react preferentially with $\mathrm{HO}_{2}$ radicals to form hydroxy hydroperoxides and peroxy acids with lower volatility, leading to higher SOA yields. Experiments performed in the presence of $\mathrm{NO}_{\mathrm{x}}$ also showed that $\mathrm{SOA}$ yields are higher for high $\mathrm{NO}_{2} / \mathrm{NO}$ ratios (3 to 8) (Chan et al., 2010). This result is due to the dominating $\mathrm{RO}_{2}+\mathrm{NO}_{2}$ reaction, which leads to PAN-like compounds. In particular, MPAN (peroxy methacryloyl nitrate) was identified as an important intermediate to SOA formation from isoprene and MACR in the presence of $\mathrm{NO}_{\mathrm{x}}$ (Surratt et al., 2010). MPAN formation is thus suppressed or delayed in the presence of high initial concentrations of NO, leading to lower SOA yields at low $(<1)$ initial VOC / NO ratios (Zhang et al., 2012).

Due to the identified link between MPAN and SOA formation from MACR, and the high degree of similarity of SOA mass spectra from isoprene and MACR photooxidation, MACR was recognized as the major contributor to SOA formation from isoprene in the presence of $\mathrm{NO}_{\mathrm{x}}$ (Kroll et al., 2006; Surratt et al., 2006). Its gas-phase primary oxidation products in the presence of $\mathrm{NO}_{\mathrm{x}}$ are $\mathrm{CO}, \mathrm{CO}_{2}, \mathrm{HCHO}$, hydroxyacetone, methylglyoxal and MPAN (Galloway et al., 2011; Orlando et al., 1999; Tuazon and Atkinson, 1990b). SOA yields from MACR are globally higher than SOA yields from isoprene and are also influenced by $\mathrm{NO}_{2} / \mathrm{NO}$ ratios (Chan et al., 2010).

Although the influence of $\mathrm{NO}_{\mathrm{x}}$ levels on SOA yields from isoprene and MACR photooxidation is recognized, it cannot fully explain the high degree of variability observed among studies from the literature. As pointed out by Carlton et al. (2009), this variability can be explained by differences in $\mathrm{OH}$ concentrations (that are related to the employed radical precursor) which have an important impact on the extent of the reactions and the rate of formation of semi-volatile compounds. Other experimental parameters, far less studied, could also contribute to the observed variability in SOA yields, including the effects of different light sources as well as the role of the chamber walls. It was demonstrated by Zhang et al. (2014) that wall losses of semi-VOCs during photooxidation experiments can lead to lower SOA yields. Furthermore, Warren et al. (2008) used black lights and an argon arc lamp (which exhibits an emission spectrum more similar to the solar spectrum) on the $m$-xylene/NO $\mathrm{NO}_{\mathrm{x}}$ photooxidation system and they observed an effect of the irradiation wavelength spectrum on the SOA yields. It was suggested that black lights may be missing photolysis reactions which are important in SOA formation, leading to an increase in SOA yields when the argon arc lamp was used.

In this work, we investigate the formation of gas-phase first- and higher-generation products and SOA during isoprene and MACR $+\mathrm{OH}$ reactions in the presence of $\mathrm{NO}_{\mathrm{x}}$. The experiments have been carried out in a stainless steel chamber with very realistic irradiation to study the possible effect of the light source used and the state of cleanliness of the walls on SOA yields.

\section{Experimental section}

Experiments were performed in the CESAM chamber (French acronym for experimental multiphasic atmospheric simulation chamber), described in detail elsewhere (Wang et al., 2011). This $4.2 \mathrm{~m}^{3}$ cylindrical stainless steel chamber is equipped with three high-pressure xenon arc lamps and Pyrex ${ }^{\circledR}$ filters of $6.5 \mathrm{~mm}$ thickness that provide, inside the chamber, an irradiation with a spectrum that is very close to the solar spectrum at the ground level (Fig. S1 in the Supplement). For these experiments, $\mathrm{NO}_{2}$ photolysis frequency was $2.8 \times 10^{-3} \mathrm{~s}^{-1}$. In order to avoid an increase of temperature during experiments due to irradiation, a cooling system was used. The system is based on the circulation of a liquid coolant (70\% water and $30 \%$ ethylene glycol) in the chamber double wall. The liquid's circulation and temperature were controlled by a thermostat (LAUDA, Integral T10000 W). Temperature and relative humidity (RH) inside the chamber were continuously monitored by a Vaisala HU- 
Table 1. Experimental conditions and results.

\begin{tabular}{|c|c|c|c|c|c|c|c|c|c|c|}
\hline Experiment $^{\mathrm{a}, \mathrm{b}}$ & $\begin{array}{r}{[\mathrm{VOC}]_{0}^{\mathrm{h}}} \\
\mathrm{ppb}\end{array}$ & $\begin{array}{r}\mathrm{OH} \\
\text { source }\end{array}$ & $\begin{array}{r}{[\mathrm{NO}]_{0}} \\
\mathrm{ppb}\end{array}$ & $\begin{array}{r}{\left[\mathrm{NO}_{2}\right]_{0}} \\
\mathrm{ppb}\end{array}$ & $\begin{array}{r}{\left[\mathrm{HONO}_{0}\right.} \\
\mathrm{ppb}\end{array}$ & $\begin{array}{r}{\left[\mathrm{O}_{3}\right]_{\max }} \\
\mathrm{ppb}\end{array}$ & $\begin{array}{c}T \\
{ }^{\circ} \mathrm{C}\end{array}$ & $\mu \mathrm{m}^{3} \mathrm{~cm}_{\mathrm{AS}, 0}^{\mathrm{e}}$ & $\begin{array}{c}\Delta \mathrm{M}_{0}^{\mathrm{f}, \mathrm{i}} \\
\mu \mathrm{g} \mathrm{m}^{-3}\end{array}$ & SOA mass yield \\
\hline \multicolumn{11}{|c|}{ Isoprene } \\
\hline I150211 & 473 & $\mathrm{NO}_{\mathrm{x}}$ & 119 & 32 & - & 347 & 18.1 & - & 8.4 & $0.006\left( \pm 5.10^{-4}\right)$ \\
\hline I160211 & 500 & $\mathrm{NO}_{\mathrm{x}}$ & 14 & 79 & - & 546 & 16.4 & - & 4.7 & $0.003\left( \pm 3.10^{-4}\right)$ \\
\hline I170211 & 485 & $\mathrm{NO}_{\mathrm{x}}$ & 22 & 55 & - & 397 & 16.6 & - & 1.6 & $0.001\left( \pm 1.10^{-4}\right)$ \\
\hline I050411 & 465 & $\mathrm{NO}_{\mathrm{x}}$ & 110 & 4 & - & 495 & 20 & - & 12.4 & $0.010\left( \pm 7.10^{-4}\right)$ \\
\hline I060411 & 458 & $\mathrm{NO}_{\mathrm{x}}$ & 135 & 5 & - & 300 & 21.1 & - & 7.3 & $0.006\left( \pm 5.10^{-4}\right)$ \\
\hline I080411 & 465 & $\mathrm{NO}_{\mathrm{x}}$ & 109 & 3 & - & 286 & 20.8 & 16.2 & 5.5 & $0.004\left( \pm 3.10^{-4}\right)$ \\
\hline I1 10411 & 462 & $\mathrm{NO}_{\mathrm{x}}$ & 127 & 5 & - & 359 & 21.9 & 12.9 & 6.2 & $0.005\left( \pm 4.10^{-4}\right)$ \\
\hline I150512 & 452 & $\mathrm{NO}_{\mathrm{x}}$ & 101 & $<1$ & - & 174 & 21.4 & - & 7.8 & $0.006\left( \pm 5.10^{-4}\right)$ \\
\hline I160512 & 445 & $\mathrm{NO}_{\mathrm{x}}$ & 117 & $<1$ & - & 175 & 20.6 & - & 4.4 & $0.004\left( \pm 3.10^{-4}\right)$ \\
\hline $\mathrm{I} 210512^{\mathrm{g}}$ & 442 & $\mathrm{NO}_{\mathrm{x}}$ & 110 & $<1$ & - & 183 & 22.2 & - & $<0.1$ & 0 \\
\hline I220512 & 444 & $\mathrm{NO}_{\mathrm{x}}$ & 111 & $<1$ & - & 113 & 21 & - & 0.3 & 0 \\
\hline I230512 & 439 & $\mathrm{NO}_{\mathrm{x}}$ & 21 & 76 & - & 131 & 24.3 & - & 0.1 & 0 \\
\hline I1601139 & 846 & HONO & 143 & $27^{\mathrm{d}}$ & 15 & 122 & 21.5 & - & $<0.1$ & 0 \\
\hline I280113g & 833 & HONO & 88 & $45^{\mathrm{d}}$ & 125 & 201 & 18.3 & - & 2.8 & $0.001\left( \pm 9.10^{-5}\right)$ \\
\hline I130313g & 840 & HONO & 66 & $<1^{\mathrm{d}}$ & 45 & 54 & 17.5 & - & 2.4 & $0.001\left( \pm 8.10^{-5}\right)$ \\
\hline $\mathrm{I} 250313^{\mathrm{g}}$ & 802 & HONO & 137 & $48^{\mathrm{d}}$ & 121 & 81 & 19.7 & - & 0.15 & 0 \\
\hline \multicolumn{11}{|c|}{ Methacrolein } \\
\hline M120411 & 474 & $\mathrm{NO}_{\mathrm{x}}$ & 117 & 4 & - & 145 & 19 & 14.8 & 17.4 & $0.013\left( \pm 9.10^{-4}\right)$ \\
\hline M130411 & 480 & $\mathrm{NO}_{\mathrm{x}}$ & 123 & 4 & - & 130 & 20.8 & 13.5 & 13.9 & $0.010\left( \pm 7.10^{-4}\right)$ \\
\hline M240512 & 457 & $\mathrm{NO}_{\mathrm{x}}$ & 19 & 84 & - & 97 & 24.2 & - & 9.5 & $0.008\left( \pm 6.10^{-4}\right)$ \\
\hline M250512 & 405 & $\mathrm{NO}_{\mathrm{x}}$ & 26 & 100 & - & 46 & 24 & - & 5.0 & $0.005\left( \pm 5.10^{-4}\right)$ \\
\hline M280512 & 403 & $\mathrm{NO}_{\mathrm{x}}$ & n.m. ${ }^{\mathrm{c}}$ & 80 & - & 59 & 23.8 & - & 9.4 & $0.009\left( \pm 8.10^{-4}\right)$ \\
\hline M180113g & 735 & HONO & 88 & $25^{\mathrm{d}}$ & 124 & 94 & 19.8 & - & 58.8 & $0.03\left( \pm 1.10^{-3}\right)$ \\
\hline M210113 & 927 & HONO & 118 & $81^{\mathrm{d}}$ & 150 & 123 & 19.4 & - & 65.8 & $0.032\left( \pm 1.10^{-3}\right)$ \\
\hline M230113g & 396 & HONO & 67 & $5^{\mathrm{d}}$ & 125 & 51 & 19.6 & - & 27.3 & $0.028\left( \pm 3.10^{-3}\right)$ \\
\hline M250113g & 445 & HONO & 39 & $8^{d}$ & 60 & 31 & 18.8 & - & 7.8 & $0.007\left( \pm 6.10^{-4}\right)$ \\
\hline M110313g & 400 & HONO & 107 & $38^{\mathrm{d}}$ & 91 & 17 & 21.8 & - & 44.8 & $0.042\left( \pm 3.10^{-3}\right)$ \\
\hline
\end{tabular}

a All experiments were carried out at $\mathrm{RH}<5 \%$. ${ }^{\mathrm{b}}$ Experimental IDs starting with "I" indicate isoprene photooxidation experiments and experimental IDs starting with "M" indicate methacrolein photooxidation experiments. ${ }^{\mathrm{c}}$ Not measured. ${ }^{\mathrm{d}}$ Corrected from HONO interference. ${ }^{\mathrm{e}}$ Volume concentration of ammonium sulfate seed. ${ }^{\mathrm{f}}$ SOA mass concentration using an effective density of $1.4 \mathrm{~g} \mathrm{~cm}^{-3}$ (see text). ${ }^{\mathrm{g}}$ Experiment with manual cleaning the day before. ${ }^{\mathrm{h}}$ Measurement uncertainty is \pm 15 ppb. ${ }^{\mathrm{i}} \mathrm{Measurement}$ uncertainty is $\pm 0.1 \mu \mathrm{g} \mathrm{m}^{-3}$.

MICAP HMP234 probe. Due to the very low level of charges on the walls (conductive and grounded), aerosols exhibit a long lifetime (between $10 \mathrm{~h}$ and 4 days, depending on the particle size distribution) in the chamber (McMurry and Rader, 1985; Wang et al., 2011).

\subsection{Chamber conditioning}

Prior to each experiment, the chamber was cleaned by overnight pumping at a secondary vacuum in the range of $6 \times 10^{-4}$ mbar. This procedure has shown very satisfactory results for most chemical systems (Wang et al., 2011). In the case of isoprene photooxidation, due to the expected low aerosol yield, several experiments were preceded by an additional manual cleaning (Table 1). This manual cleaning was performed using ultrapure water (18.2 M $\Omega$, ELGA Maxima) and lint free wipes (Spec-Wipe ${ }^{\circledR}$ 3), then the cham- ber walls were heated at $40^{\circ} \mathrm{C}$ prior to overnight pumping. This procedure leads to experiments with very high initial level of cleanliness of the chamber walls, leading to low $\mathrm{OH}$ formation due to low nitrous acid (HONO) formation from $\mathrm{NO}_{\mathrm{x}}$ wall reaction at the beginning of the experiment $\left(<5 \times 10^{5} \mathrm{molec}^{-3}\right.$, see Fig. S2), thus requiring additional HONO introduction (Table 1).

After overnight pumping, the chamber was filled with synthetic air produced by mixing approximately 800 mbar of $\mathrm{N}_{2}$ produced from the evaporation of a pressurized liquid nitrogen tank, and around 200 mbar of $\mathrm{O}_{2}$ (Linde, 5.0). A known pressure of isoprene (Sigma Aldrich, $99 \%$ ), or methacrolein (Sigma Aldrich, 95\%), prepared in a known volume glass bulb was then introduced into the chamber by flushing with a low flow of $\mathrm{O}_{2}$. Two different $\mathrm{OH}$ precursors were used: $\mathrm{NO}_{\mathrm{x}}$ wall reaction (Wang et al., 2011) and $\mathrm{HONO} . \mathrm{NO}_{2}$ in- 
jection (Air Liquide, Alphagaz $99.9 \%$ purity) in the chamber was made using a gas syringe and a septum valve. $\mathrm{NO}$ was injected from a gas cylinder (Air Liquide, 8 ppm in $\mathrm{N}_{2}$ ) using a mass flow controller. HONO was prepared by a dropwise addition of sulfuric acid $\left(10^{-2} \mathrm{M}\right)$ into a solution of $\mathrm{NaNO}_{2}$ $(0.1 \mathrm{M})$ and carried into the chamber with a flow of pure $\mathrm{N}_{2}$. During this synthesis, $\mathrm{NO}_{\mathrm{x}}$ were also formed and introduced in the chamber. For some experiments, inorganic seed particles were generated from a $0.0012 \mathrm{M}$ aqueous ammonium sulfate solution using a constant output atomizer (TSI, model 3075) and were injected into the chamber through a diffusion dryer (TSI, model 3062). The irradiation started after these injections and lasted for 6 to $9 \mathrm{~h}$. Unless specified, time 0 denotes the irradiation start.

In order to avoid a decrease in the $\mathrm{OH}$ production efficiency due to a fast consumption of $\mathrm{NO}$ in the first hours of the experiment (see Fig. S3), a low $\left(0.3 \mathrm{~L} \mathrm{~min}^{-1}\right)$ flow of NO (Air Liquide, $8 \mathrm{ppm}$ in $\mathrm{N}_{2}$ ) was continuously introduced into the chamber. The NO flow was started only when NO mixing ratio in the system reached a concentration below $5 \mathrm{ppb}$ and was manually adjusted to avoid an accumulation of $\mathrm{NO}$ in the system in order to maintain a $\mathrm{NO}$ mixing ratio between 2 and $5 \mathrm{ppb}$ during the entire experiment. The pressure inside the chamber was maintained at a pressure slightly higher than the ambient by applying a flow of air $\left(80 \% \mathrm{~N}_{2}\right.$ and $\left.20 \% \mathrm{O}_{2}\right)$ to offset the pressure loss due to the continuous sampling. The experimental initial conditions are summarized in Table 1.

\subsection{Measurements}

The gas-phase concentrations of isoprene, MACR, MVK, HCHO, PAN, methylglyoxal, MPAN, formic acid, carbon monoxide $(\mathrm{CO})$ and $\mathrm{NO}_{2}$ were monitored by Fourier transform infrared spectrometry (FTIR, Bruker ${ }^{\circledR}$, TENSOR 37) interfaced with an in situ multiple reflection cell. To determine the contribution of the pure reference spectra to the mixture spectra, an automatic procedure based on matrix algebra was used and results were cross-checked by manual subtraction performed over selected spectra. Complementarily to FTIR measurements, a proton-transfer time of flight mass spectrometer (PTR-ToF-MS 8000, Ionicon Analytik ${ }^{\circledR}$ ) was used for online gas-phase measurements in the $\mathrm{m} / \mathrm{z}$ range 10-200 including isoprene, the sum of \{methacrolein + methyl vinyl ketone\}, formaldehyde, methylglyoxal, formic acid, 3-methylfuran (3-MF), acetaldehyde, the sum of $\{$ acetic acid + glycolaldehyde $\}$, acetone, acrolein (using the $\left(\mathrm{C}_{3} \mathrm{H}_{4} \mathrm{O}\right) \mathrm{H}^{+}$ion signal, contribution from fragmentation of higher-molecular weight products could not be excluded), hydroxyacetone, and a few other oxygenated VOCs. Pure standards tests were previously carried out to identify fragmentation patterns and sensitivities of the main oxidation products. The signal of the PTR-ToFMS was calibrated using a certified gas standard mixture (EU Version TO-14A Aromatics 110 L, 100 ppbv each) be- fore the set of experiments. Parameters of the PTR-ToF-MS during the series of measurements were as follows: drift tube voltage: $500 \mathrm{~V}$, drift tube pressure $\approx 2.15 \mathrm{mbar}$, drift tube temperature: $353 \mathrm{~K}$, resulting in a $E / N$ of $120125 \mathrm{Td}$ ( $E$ being the electric field strength applied to the drift tube and $N$ the density of the gas in the drift tube) $\left(1 \mathrm{Td}=10^{-17} \mathrm{~V} \mathrm{~cm}^{-2}\right)$. Data analysis of the PTR-ToF-MS measurements was carried out using the ToFViewer ${ }^{\circledR}$ software. ToF-to-mass assignment was performed using hydronium ion isotope $\left(\mathrm{H}_{3}^{18} \mathrm{O}^{+} \mathrm{m} / z=21.023\right)$ and protonated acetone $\left(\mathrm{C}_{3} \mathrm{H}_{7} \mathrm{O}^{+} m / z=59.049\right)$. The mass resolution $\mathrm{m} / \Delta \mathrm{m}$ of 4000 (at full width at half maximum) was achieved with the PTR-ToF-MS during the series of experiments. This enabled separation and formula assignment for most of the ions comprising the mass spectra. Some VOCs were measured using both FTIR and PTR-ToF-MS (isoprene, formaldehyde, methyl vinyl ketone, methacrolein, ...), thus providing intercalibration of their PTR-ToF-MS signal with the FTIR derived concentrations. Ozone was measured by a commercial UV absorption monitor (Horiba ${ }^{\circledR}$, APOA-370). A commercial chemiluminescence $\mathrm{NO}_{\mathrm{x}}$ analyzer (Horiba ${ }^{\circledR}$, APNA370) was used to monitor $\mathrm{NO}$. Interferences on the $\mathrm{NO}_{2}$ signal from the $\mathrm{NO}_{\mathrm{x}}$ monitor could occur due to the presence of $\mathrm{NO}_{\mathrm{y}}$ during the experiments (Dunlea et al., 2007), $\mathrm{NO}_{2}$ mixing ratio was therefore determined using FTIR data.

HONO was measured using an instrument constructed in-house (NitroMAC) based on a wet chemical derivatization technique and high performance liquid chromatography - visible (HPLC-VIS) detection (Zhou et al., 1999). Gaseous HONO was sampled by dissolution in a buffer phosphate solution followed by derivatization with an aqueous sulphanilamide/N-(1-naphthyl)-ethylenediamine solution (SA/NED).

A scanning mobility particle sizer (SMPS) was used to monitor aerosol total number and volume concentrations and size distributions from 10.9 to $478 \mathrm{~nm}$. It consists of a differential mobility analyzer (DMA, TSI, model 3080) coupled with a condensation particle counter (CPC, TSI, model 3010). The non-refractory submicron particulate matter bulk chemical composition was measured using a high resolution time-of-flight aerosol mass spectrometer (AMS, Aerodyne) (Canagaratna et al., 2007; De Carlo et al., 2006). The instrument was used under standard conditions (vaporizer at $600^{\circ} \mathrm{C}$ and electron ionization at $70 \mathrm{eV}$ ) and operated in MS mode ( $V$ and $W, 30 \mathrm{~s}$ each) and PToF mode $(60 \mathrm{~s})$. Ammonium nitrate particles were used regularly to perform standard AMS calibration procedures (including brute force single particle (BFSP) ionization efficiency calibration and size calibration). The AMS data were analyzed using the standard fragmentation table with the corrected air fragment column for our carrier gas, the default values of relative ionization efficiency and a collection efficiency of 0.5 for the organics (Squirrel ToF-AMS Analysis $1.51 \mathrm{H}$ and Pika ${ }^{\circledR}$ ToFAMS HR Analysis $1.10 \mathrm{H}$ packages for the software Igor ${ }^{\circledR}$ Pro 6.21). 


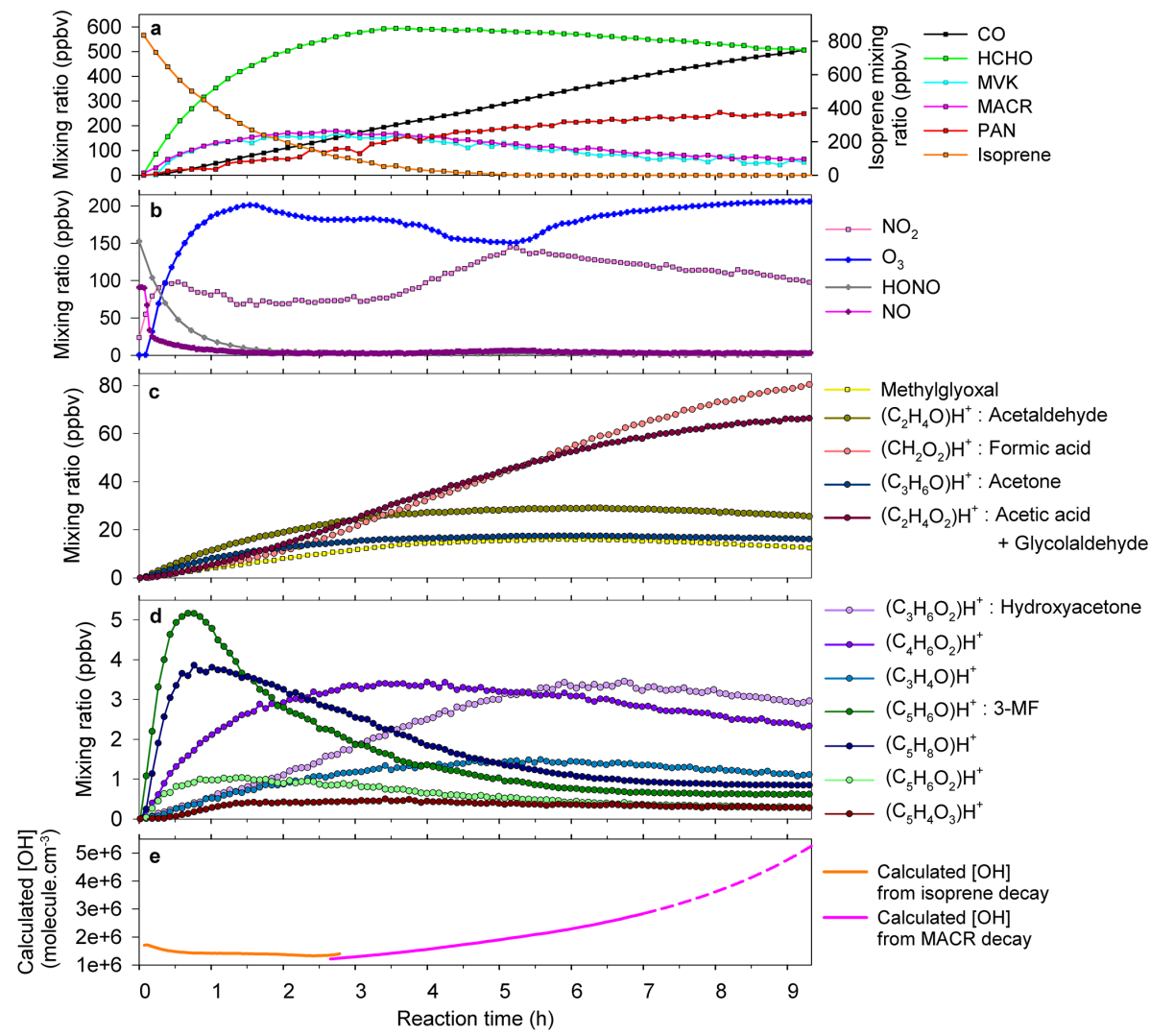

Figure 1. Time profiles of gas-phase measured compounds and calculated $\mathrm{OH}$ concentrations during isoprene photooxidation (experiment I280113) performed with no seeds and with HONO as OH source. PTR-ToF-MS measurements are represented by circles, and FTIR measurements, by squares. Calculated $[\mathrm{OH}]$ is represented by a dotted line after $7 \mathrm{~h}$ of irradiation due to low MACR mixing ratios which implies less precision in the calculation as the contribution from other VOCs is not negligible.

\section{Results and discussion}

\subsection{Isoprene experiments}

Figure 1 shows the time profiles of the gas phase reactants and reaction products during an isoprene photooxidation experiment performed without inorganic seed and using HONO as $\mathrm{OH}$ precursor. The irradiation induced a fast consumption of $\mathrm{NO}$, leading to an increase of $\mathrm{NO}_{2}$ concentrations via $\mathrm{NO}$ to $\mathrm{NO}_{2}$ conversion (Fig. 1b). Isoprene concentration decay was also observed (Fig. 1a) and its lifetime due to reaction with $\mathrm{OH}\left(\tau_{\text {isoprene- }} \mathrm{OH}\right)$ was determined considering the time needed to divide the initial isoprene concentration by a factor $e$. In all our experiments, $\tau_{\text {isoprene-OH }}$ was $1.7 \pm 0.4 \mathrm{~h}$ (except for I160113 and I130313 in which isoprene lifetime was 1 and $2 \mathrm{~h}$ longer, respectively), thus close to the atmospheric isoprene lifetime (Karl et al., 2006). During isoprene photooxidation, $\mathrm{NO}$ reacts with $\mathrm{RO}_{2}$ and $\mathrm{HO}_{2}$ radicals to form $\mathrm{NO}_{2}$ which photolyzes and leads to ozone production, thus explaining the observation of $\mathrm{O}_{3}$ mixing ratios reaching up to several hundred ppbv (Fig. 1b). Despite these high $\mathrm{O}_{3}$ mixing ratios, isoprene oxidation was dominated by $\mathrm{OH}$ radicals during all experiments, due to the higher reactivity of isoprene towards $\mathrm{OH}$ radicals than ozone (Karl et al., 2006).

\subsubsection{Determination of $\mathrm{OH}$ concentrations}

The $\mathrm{OH}$ concentrations and their time profiles were estimated from the observed decay rate of isoprene and methacrolein (using polynomial fit curves). The loss of VOC (i.e., either isoprene or methacrolein) was corrected from their reaction with ozone, photolysis and dilution, using Eq. (1):

$$
\begin{aligned}
& {[\mathrm{OH}]_{i}=\frac{1}{k_{\mathrm{OH}+\mathrm{VOC}}}\left(-\frac{1}{[\mathrm{VOC}]_{i}} \times \frac{\Delta[\mathrm{VOC}]}{\Delta t}\right.} \\
& \left.-k_{\mathrm{O}_{3}}+\mathrm{VOC}\left[\mathrm{O}_{3}\right]_{i}-k_{\mathrm{dil}}-J_{\mathrm{VOC}}\right),
\end{aligned}
$$

where $\frac{\Delta[\mathrm{VOC}]}{\Delta t}$ is the time variation of the VOC mixing ratios, $k_{\mathrm{OH}+\mathrm{VOC}}$ and $k_{\mathrm{O}_{3}+\mathrm{VOC}}$ are the rate coefficients for reaction with, respectively, $\mathrm{OH}$ and $\mathrm{O}_{3}$ (from Atkinson et al., 2006), $k_{\mathrm{dil}}$ is the dilution rate, and $J_{\mathrm{VOC}}$ is the photolysis rate of the VOC. $J_{\mathrm{VOC}}$ was determined for MACR ( $\left.J_{\mathrm{MACR}}\right)$ using MACR absorption cross-section and quantum yields (Atkinson et al., 2006), and xenon arc lamp irradiation spectrum with $6.5 \mathrm{~mm}$ Pyrex $^{\circledR}$ filters (Fig. S1). The value for 
$k_{\text {dil }}$ was determined using the air flow rate used to offset the loss of pressure due to sampling and was found to be around $1.6 \times 10^{-5} \mathrm{~s}^{-1}$. The $\mathrm{OH}$ concentrations were calculated from the isoprene decay until its concentration became too low, and then the MACR decay was used. The resulting $\mathrm{OH}$ concentrations ranged between $1.5 \times 10^{6}$ and $6 \times 10^{6}$ molec $\mathrm{cm}^{-3}$, thus showing that the protocol used (low flow of diluted NO continuously introduced) allowed to maintain an $\mathrm{OH}$ level in the chamber of the same order of magnitude as the one of the atmosphere during the entire experiment length (Fig. 1e).

\subsubsection{Isoprene gas-phase reaction products}

The major first generation products of isoprene $\mathrm{OH}$ oxidation were MACR, HCHO and MVK (Fig. 1a, FTIR measurements), two minor first generation products (3-MF and $\mathrm{C}_{5} \mathrm{H}_{8} \mathrm{O}$, see Fig. 1d) were also detected by the PTR-ToFMS. Plotting the concentration (dilution corrected) of each first generation products versus the reacted isoprene concentration $\left([\text { product }]_{\mathrm{corr}, t}=f\left([\text { isoprene }]_{0}-[\text { isoprene }]_{t}\right)\right.$ ) during the first hour of photooxidation (i.e., when photolysis and reaction with $\mathrm{OH}$ of the primary products were not significant), provided linear curves. The corresponding slope gave the yield for each first-generation product. Table 2 shows that, due to the indicated uncertainties, no significant differences between the obtained yields and those from the literature were observed. They were thus in good agreement.

Thanks to the continuous $\mathrm{OH}$ radical concentrations maintained throughout the experiments, the consumption of the primary products leading to the formation of compounds of higher generation was clearly seen (Fig. 1a, c, d). Among these compounds, PAN, methylglyoxal, glycolaldehyde and hydroxyacetone were previously identified as major primary oxidation products of MACR and MVK (Galloway et al., 2011; Orlando et al., 1999; Tuazon and Atkinson, 1990b, 1989). Other species generally observed in isoprene photooxidation experiments as acetaldehyde, formic acid and acetone (Nguyen et al., 2011b; Paulot et al., 2009) were also observed (Fig. 1c). Some other compounds were not clearly identified considering only their molecular formula given by PTRToF-MS measurements, but some assumptions can be made. We measured $\mathrm{C}_{5} \mathrm{H}_{8} \mathrm{O}$ (Fig. 1d), which seems to be a primary product (with a yield around $1 \%$ ), it may be attributed to 2-methylbut-3-enal. The latter was identified in the gas phase by Healy et al. (2008) in the same type of experiments. The yield for this compound was determined considering only the $\left(\mathrm{C}_{5} \mathrm{H}_{8} \mathrm{O}\right) \mathrm{H}^{+}$ion signal and assuming no contribution from fragmentation of higher-molecular weight products. This unsaturated $\mathrm{C}_{5}$ carbonyl compound can be formed, like the other primary products, from $\mathrm{OH}$ addition to one of the isoprene double bonds, followed by oxidation of the hydroxyalkyl radical produced. Compound $\mathrm{C}_{5} \mathrm{H}_{6} \mathrm{O}_{2}$ (Fig. 1d) could correspond to methylbutandial, that was assumed to be formed by the $\delta$-hydroxy channels including 3-MF reaction
Table 2. Yields of first-generation oxidation products during isoprene photooxidation compared with previous studies. Values in parentheses are 2-sigma uncertainties.

\begin{tabular}{|c|c|c|}
\hline Compound & Yield & Reference \\
\hline \multirow{4}{*}{ Formaldehyde } & $0.75( \pm 0.11)$ & This work \\
\hline & $0.63( \pm 0.10)$ & \\
\hline & $0.57(+0.06)$ & $\begin{array}{l}\text { (1990a) } \\
\text { Mivoshi et al (1994) }\end{array}$ \\
\hline & $0.59( \pm 0.12)$ & $\begin{array}{l}\text { Sprengnether et al. } \\
\text { (2002) }\end{array}$ \\
\hline \multirow{7}{*}{ Methacrolein } & $0.30( \pm 0.09)$ & This work \\
\hline & $0.22( \pm 0.05)$ & $\begin{array}{l}\text { Tuazon and Atkinson } \\
\text { (1990a) }\end{array}$ \\
\hline & $0.25( \pm 0.03)$ & Paulson et al. (1992) \\
\hline & $0.22( \pm 0.02)$ & Miyoshi et al. (1994) \\
\hline & $0.27( \pm 0.04)$ & $\begin{array}{l}\text { Sprengnether et al. } \\
(2002)\end{array}$ \\
\hline & $0.22( \pm 0.006)$ & $\begin{array}{l}\text { Galloway et al. } \\
\text { (2011) }\end{array}$ \\
\hline & $0.27( \pm 0.03)$ & Karl et al. (2006) \\
\hline \multirow{7}{*}{ Methyl vinyl ketone } & $0.27( \pm 0.08)$ & This work \\
\hline & $0.32( \pm 0.07)$ & $\begin{array}{l}\text { Tuazon and Atkinson } \\
\text { (1990a) }\end{array}$ \\
\hline & $0.36( \pm 0.04)$ & Paulson et al. (1992) \\
\hline & $0.32( \pm 0.05)$ & Miyoshi et al. (1994) \\
\hline & $0.44( \pm 0.06)$ & $\begin{array}{l}\text { Sprengnether et al. } \\
(2002)\end{array}$ \\
\hline & $0.30( \pm 0.01)$ & $\begin{array}{l}\text { Galloway et al. } \\
\text { (2011) }\end{array}$ \\
\hline & $0.41( \pm 0.03)$ & Karl et al. (2006) \\
\hline \multirow{4}{*}{ 3-Methylfuran } & $0.033( \pm 0.014)$ & This work \\
\hline & $0.048( \pm 0.006)$ & Tuazon and Atkinson \\
\hline & $0.04( \pm 0.02)$ & $\begin{array}{l}\text { (1990a) } \\
\text { Paulson et al. (1992) }\end{array}$ \\
\hline & $<0.001$ & $\begin{array}{l}\text { Sprengnether et al. } \\
\text { (2002) }\end{array}$ \\
\hline
\end{tabular}

with OH (Paulot et al., 2009). It was also suggested by Paulot et al. (2009) that the $\delta$-hydroxy channels lead to the formation of 3-oxobutanal, with a molecular formula corresponding to $\mathrm{C}_{4} \mathrm{H}_{6} \mathrm{O}_{2}$, that we also observed (Fig. 1d). Species with this molecular formula could also be hydroxy methyl vinyl ketone (Galloway et al., 2011). MPAN concentrations were detected (but not quantified) by the PTR-ToF-MS at the $\left(\mathrm{C}_{4} \mathrm{H}_{6} \mathrm{O}_{3}\right) \mathrm{H}^{+}$ion $(m / z$ 103) (Hansel and Wisthaler, 2000). This compound was not detected by FTIR; thus, it was deduced that its mixing ratios were below the FTIR detection limit (i.e., 5 ppb).

\subsubsection{Isoprene-SOA yields}

Figure 2 shows a typical time profile of SOA mass and number size distributions during isoprene $\mathrm{OH}$-oxidation without seed particles. In all experiments, SOA formation started when a major part (> $80 \%$ ) of isoprene was consumed, i.e., 


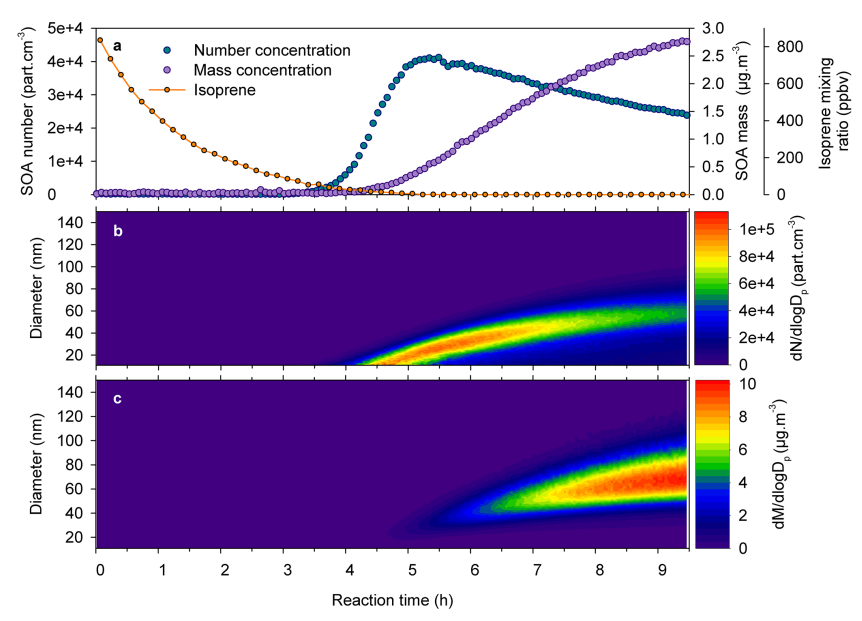

Figure 2. Time profiles of measured (a) SOA mass and number concentrations, (b) number size distribution and (c) mass size distribution during isoprene photooxidation (experiment I280113) performed with no seeds and with $\mathrm{HONO}$ as $\mathrm{OH}$ source. A particle density of $1.4 \mathrm{~g} \mathrm{~cm}^{-3}$ was assumed (see text).

$2 \mathrm{~h}$ (minimum) after the irradiation started. Particle number concentrations showed a sharp increase at the onset of SOA formation and then, a gradual decrease with a corresponding rise in average particle diameter due to coagulation (Fig. 2a, c). SOA growth continued even after isoprene complete consumption and the aerosol mass typically reached a maximum after approximately $7-9 \mathrm{~h}$ of irradiation (showing the importance of maintaining $\mathrm{OH}$ level during several hours). These observations are typical of an SOA formation induced from the oxidation of secondary products as observed by $\mathrm{Ng}$ et al. (2006). At the end of the experiment, particle mean mass diameter was around $85 \mathrm{~nm}$. Table 1 shows that the maximum SOA mass observed during these experiments ranged from less than 0.1 to $12.4 \mu \mathrm{g} \mathrm{m}^{-3}$. Even if sometimes this SOA formation was very low, it was considered significant due to observed differences with control experiments (irradiation of a synthetic air / $\mathrm{NO}_{\mathrm{x}} / \mathrm{HONO}$ mixture during several hours). Indeed, control experiments did not allow the detection of any significant aerosol formation with particle number remaining in the range of a few tens of particles per cubic centimeter when any experiment presented in Table 1 led to the formation of several thousands of particles per cubic centimeter (or more) even when the SOA mass remained very small.

Once SOA mass was stabilized, aerosol yields $(Y)$ were calculated following Eq. (2):

$$
Y=\frac{\Delta M_{0}}{\Delta[\text { isoprene }]},
$$

where $\Delta M_{0}$ is the mass concentration of SOA formed and $\Delta$ [isoprene] is the mass concentration of isoprene reacted. All values were dilution corrected. Similarly to what has been shown by Wang et al. (2011), particles wall losses were not significant in our experiments (see Fig. S4). The comparison of the mobility diameter (obtained from the SMPS measurements) and the vacuum aerodynamic diameter (measured by the AMS) (as described by Bahreini et al., 2005) lead to the SOA effective density of $1.4 \mathrm{~g} \mathrm{~cm}^{-3}$ in good agreement with previous studies carried out in the presence of $\mathrm{NO}_{\mathrm{x}}$ (Dommen et al., 2006; Kroll et al., 2005). Aerosol volume concentrations were converted to mass concentrations using this value.

As shown in Table 1, the isoprene-SOA yields are low and range from 0.1 to $1 \%$. In our experiments, the initial $\mathrm{NO}_{2} / \mathrm{NO}$ or isoprene / NO ratios did not influence the SOA yields. Our initial $\mathrm{NO}_{2} / \mathrm{NO}$ ratios varied from 0.01 to 5.64, and isoprene / NO, from 3.4 to 35 , it is thus possible that the lower values of these ratios were already too high in our experiments to observe any impact on SOA yields (Chan et al., 2010; Zhang et al., 2012). No direct effect of the average $\mathrm{NO}_{2} / \mathrm{NO}$ ratio (during isoprene decay), which ranged from 4 to 50, was detected. There was no obvious dependence of SOA yields on the presence of seed particles and on the $\mathrm{OH}$ radical precursor used. In order to explain our very low yields, especially those obtained after the manual cleaning (Table 1), we suspected an impact of the chamber walls' cleanliness on our SOA yields. Two hypotheses can be made: (1) when manual cleaning has been performed, high cleanliness could lead to an enhanced loss of semi-volatile reaction products that would affect the late and slow SOA growth observed for isoprene experiments; (2) in other experiments, lower cleanliness could contribute to particles formation and growth.

Concerning the first hypothesis, a higher degree of wall loss of semi-volatile species would be expected, leading to a shift in the gas and particle partitioning equilibrium, resulting in lower SOA yields. Significant loss of semi-volatile species on chamber walls was already observed in other studies carried out in Teflon film chambers (Loza et al., 2010; Matsunaga and Ziemann, 2010), and its influence on SOA yields was demonstrated by Zhang et al. (2014) in photooxidation experiments. In addition Saathoff et al. (2009) have shown that, in an aluminum chamber, considerable amounts of condensable material can be lost from the gas phase to the chamber wall in the course of an experiment and affect the SOA yield. These authors have modeled this effect and have shown that the gas mass lost to the wall could represent from $100 \%$ (for low SOA concentration condition) to $25 \%$ (at higher SOA concentration) of the measured airborne particle mass. Some pseudo-first order rates for loss processes of organic compounds in the CESAM chamber can also be found in Wang et al. (2011): although the data set is limited, these values are of the same order of magnitude as those obtained with other simulation chambers. Furthermore, an SOA yield study for a well-known system ( $\alpha$-pinene ozonolysis) is provided in this study without any significant difference with already published values. 


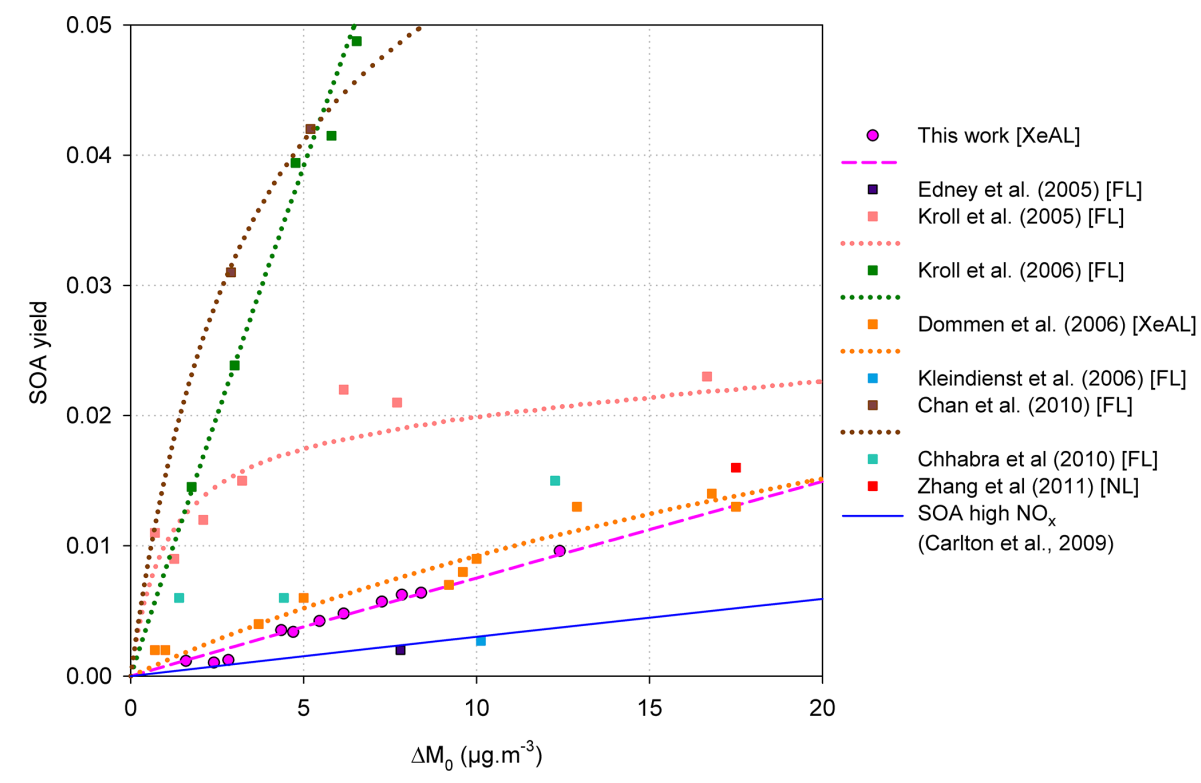

Figure 3. SOA mass yield curves from various isoprene photooxidation experiments in the presence of $\mathrm{NO}_{\mathrm{x}}$ from the literature compared with the present study. An effective density of $1.4 \mathrm{~g} \mathrm{~cm}^{-3}$ was used (see text) for conversion to mass of all our volume-based measurements. Light sources used are specified in square brackets (XeAL: xenon arc lamps; FL: fluorescent lamps; NL: natural light). The parameters of our two products yield curve (Odum et al., 1996) are as follows: $\alpha_{1}=0.508 ; K_{\mathrm{om}, 1}=7.4 \times 10^{-4} ; \alpha_{2}=0.509 ; K_{\mathrm{om}, 2}=7.4 \times 10^{-4}$.

Nevertheless, if this first hypothesis would be verified, SOA yields obtained in our study would represent lower limits. On the contrary, if the second hypothesis is right, it strongly suggests that yields obtained in other studies for this very sensitive and low productive system could be overestimated since semi-volatile species adsorbed on the walls (even in small quantities) could re-partition into the reacting mixture and contribute to particle growth.

In order to rationalize our SOA yields and compare them to the literature, the aerosol yields were plotted as a function of the organic aerosol concentrations (Odum et al., 1996). Figure 3 shows a comparison between our SOA yields from isoprene photooxidation and those from previous studies (Chan et al., 2010; Chhabra et al., 2010; Dommen et al., 2006; Edney et al., 2005; Kleindienst et al., 2006; Kroll et al., 2006, 2005; Zhang et al., 2011). Also plotted on this graph are the two products yields curves for each data set determined using Eq. (3) (Odum et al., 1996).

$Y=M_{0}\left(\frac{\alpha_{1} K_{\mathrm{om}, 1}}{1+K_{\mathrm{om}, 1} M_{0}}+\frac{\alpha_{2} K_{\mathrm{om}, 2}}{1+K_{\mathrm{om}, 2} M_{0}}\right)$,

where $\alpha_{i}$ is a stoichiometric factor, and $K_{\mathrm{om}, i}$ a gas-particle partitioning coefficient, defined according to semi-volatile partitioning theory (Pankow, 1994) for the species $i$. Despite the variability of SOA yields in this study, they were well reproduced by the two products model from Odum et al. (1996), showing that this variability was not due to a change in the chemical system but rather to a variability in its initiation or in equilibria between the walls, the gas and the particle phases. While the yields from previous studies exhibit some variation, our yields are consistent with the lowest values found in the literature. More specifically, they are very similar to those from Dommen et al. (2006) and Zhang et al. (2011). As strongly suggested by Carlton et al. (2009), the high sensitivity of the system to experimental and/or reaction conditions leads to a high degree of variability in yields measured in the different studies of isoprene photooxidation. These differences cannot be explained by the nature of the walls since studies from the literature all use Teflon chambers (Chan et al., 2010; Chhabra et al., 2010; Dommen et al., 2006; Kroll et al., 2006, 2005; Zhang et al., 2011), or stainless steel chambers with Teflon coating (Edney et al., 2005; Kleindienst et al., 2006).

Another parameter that might influence the SOA yields is the light intensity, determined as the $\mathrm{NO}_{2}$ photolysis rate. Among the studies cited in Fig. 3 (including our study), $\mathrm{J}_{\mathrm{NO} 2}$ varied from $2 \times 10^{-3}$ to $5.7 \times 10^{-3} \mathrm{~s}^{-1}$. Furthermore, it has been shown by Warren et al. (2008) that, for the $m$ xylene $/ \mathrm{NO}_{\mathrm{x}}$ photooxidation system, an increase in $\mathrm{J}_{\mathrm{NO} 2}$ of only $7 \times 10^{-4} \mathrm{~s}^{-1}$ induces an increase in SOA yields by a factor of 1.6. However, the comparison of isoprene-SOA yields obtained by Edney et al. (2005) with those by Kleindienst et al. (2006) who carried out experiments in the same simulation chamber under high $\mathrm{NO}_{\mathrm{x}}$ conditions, but with different $J_{\mathrm{NO} 2}\left(5.7 \times 10^{-3} \mathrm{~s}^{-1}\right.$ and $2.8 \times 10^{-3} \mathrm{~s}^{-1}$, respectively), shows that both yields follow the same yield curve as the one modeled by Carlton et al. (2009) for high $\mathrm{NO}_{\mathrm{x}}$ conditions (Fig. 3). In contrast, it is possible that the type of light sources used in the different studies reported in Fig. 3 plays 
a role in the SOA yield variability: the only studies who used light sources with spectra representing the solar one are those by Zhang et al. (2011) (outdoor chamber), and by Dommen et al. (2006) who used xenon arc lamps like in our study. Although fluorescent lamps used as irradiation source in the other studies (Chan et al., 2010; Chhabra et al., 2010; Edney et al., 2005; Kleindienst et al., 2006; Kroll et al., 2006, 2005) deliver a light intensity equivalent to $\mathrm{NO}_{2}$ photolysis rates which are close to natural light intensity, they exhibit emission spectra significantly different from the solar spectrum (with no emission in the longer wavelength regions, i.e above $400 \mathrm{~nm}$ ). It is thus suggested that some oxidation products contributing to the aerosol formation and growth in studies using fluorescent lamps (under similar $\mathrm{NO}_{\mathrm{x}}$ conditions), could be photolyzed in our experiments, leading to lower SOA yields. It can be noted that the photolysis of $\alpha$ dicarbonyls, for example methylglyoxal and glyoxal, may occur outside the fluorescent lamp spectrum. Average photolysis wavelengths of methylglyoxal and glyoxal are at 417 and $383 \mathrm{~nm}$, respectively (Carter et al., 1995). This hypothesis is thus opposite to the one from Warren et al. (2008) who observed higher SOA yields using an argon arc lamp (which presents a realistic irradiation spectrum) instead of black lights. However, atmospheric chemistry of aromatics is strongly different from that of alkenes, it is thus not surprising to observe a different behavior concerning relation between light source and $\mathrm{SOA}$ yields for isoprene $/ \mathrm{NO}_{\mathrm{x}}$ system.

\subsubsection{Isoprene-SOA composition}

The time profiles of elemental ratios $(\mathrm{O} / \mathrm{C}, \mathrm{H} / \mathrm{C}$ and $\mathrm{OM} / \mathrm{OC}$ ) are shown in Fig. 4. The organic mass to organic carbon ratio (OM / OC) was calculated using the equation from Aiken et al. (2007). In our experiments performed without seed particles, the very small size of the formed SOA did not allow any reliable detection by the AMS before approximately $2 \mathrm{~h}$ of SOA formation (Fig. 4a). However, the use of ammonium sulfate seed particles for two experiments (I080411 and I110411) allowed an earlier detection (Fig. 4b). This figure shows that $\mathrm{O} / \mathrm{C}$ and $\mathrm{OM} / \mathrm{OC}$ ratios increased during the first hour of SOA formation while $\mathrm{H} / \mathrm{C}$ decreased, thus exhibiting oxidation processing during the particle formation. After $2 \mathrm{~h}$ of SOA formation, all these ratios reached a plateau that remained stable until the end of the experiment. The comparison between different experiments performed under different conditions (seeds/no seeds, $\left.\mathrm{HONO} / \mathrm{NO}_{\mathrm{x}} \ldots\right)($ Fig. $4 \mathrm{a}, \mathrm{b}$ ) reveals that the final $\mathrm{O} / \mathrm{C}, \mathrm{H} / \mathrm{C}$ and $\mathrm{OM} / \mathrm{OC}$ values were highly reproducible. Thus the observed variability of the SOA yields in our experiments was likely disconnected to the elemental ratios. This reproducibility also shows that all our experiments were performed in the same chemical system. Table 3 shows that the average elemental ratios $(\mathrm{O} / \mathrm{C}, \mathrm{H} / \mathrm{C}$ and $\mathrm{OM} / \mathrm{OC})$ and their associated estimated uncertainties (as determined by Aiken et
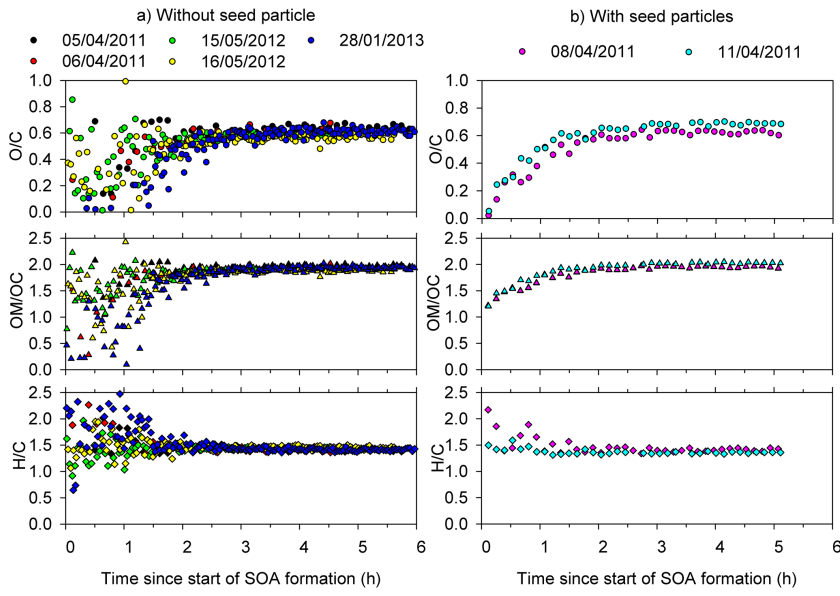

Figure 4. Time profiles of $\mathrm{O} / \mathrm{C}, \mathrm{OM} / \mathrm{OC}$ and $\mathrm{H} / \mathrm{C}$ ratios for seven different isoprene photooxidation experiments performed (a) without seed particle; (b) with ammonium sulfate seed particles.

al., 2008) are in good agreement with previous studies who carried out isoprene-SOA formation under high- $\mathrm{NO}_{\mathrm{x}}$ conditions (Aiken et al., 2008; Chhabra et al., 2010; Nguyen et al., 2011a). Furthermore, the stability of the evolution of our elemental ratios is in very good agreement with the observations by Chhabra et al. (2010). These authors related these observations to the findings by Surratt et al. (2006) who pointed out that an important pathway for isoprene-SOA formation under high $\mathrm{NO}_{\mathrm{x}}$ conditions occurs via the reactivity of MACR and MPAN that were detected in the present study. Therefore, we hereafter investigate the MACR-SOA formation under identical conditions as those performed with isoprene, and we compare the two systems.

\subsection{Methacrolein experiments}

Typical time profiles of gas-phase compounds in a MACR photooxidation experiment (M240512 in Table 1) without seeds and with $\mathrm{NO}_{\mathrm{x}}$ as $\mathrm{OH}$ source is shown in Fig. 5. Compared to isoprene experiments, ozone production was slower and reached lower maximum concentrations (Table 1), and NO consumption was slower (compare Figs. $5 b$ and $1 b$ ), thus denoting a slower oxidation process.

\subsubsection{MACR gas-phase organic reaction products}

Formaldehyde, hydroxyacetone, methylglyoxal, MPAN and $\mathrm{CO}$ (Fig. 5a, c, d) were observed in our study as the major primary MACR-oxidation products in the presence of $\mathrm{NO}_{\mathrm{x}}$. The variability in initial $\mathrm{NO}_{\mathrm{x}}$ levels impacted primary yields, values obtained were thus different between experiments. Table 4 shows that their yields were in good agreement with previous studies, except for hydroxyacetone which showed yields 4 times lower in our study. Small hydroxyacetone yields could not be explained by wall loss in our chamber considering its low decrease in concentration after 
Table 3. Average elemental ratios of SOA from isoprene and MACR photooxidation. Values in parentheses reflect the measurement uncertainty as determined by Aiken et al. (2008).

\begin{tabular}{llll}
\hline $\mathrm{O} / \mathrm{C}$ & $\mathrm{OM} / \mathrm{OC}$ & $\mathrm{H} / \mathrm{C}$ & Reference \\
\hline \multicolumn{4}{c}{ Isoprene } \\
$0.60( \pm 0.19)$ & $1.92( \pm 0.12)$ & $1.43( \pm 0.14)$ & This work without seeds \\
$0.65( \pm 0.20)$ & $1.99( \pm 0.12)$ & $1.39( \pm 0.14)$ & This work with seeds \\
$0.41( \pm 0.13)$ & $1.75( \pm 0.10)$ & - & Aiken et al. (2008) \\
$0.62( \pm 0.19)$ & $2.00( \pm 0.12)$ & $1.46( \pm 0.15)$ & Chhabra et al. (2010) \\
0.83 & 2.26 & 1.55 & Nguyen et al. (2011a) \\
$0.61( \pm 0.19)$ & $1.93( \pm 0.12)$ & Methacrolein & \\
$0.72( \pm 0.22)$ & $2.07( \pm 0.12)$ & $1.32( \pm 0.14)$ & This work without seeds \\
$0.54( \pm 0.17)$ & $1.87( \pm 0.11)$ & $1.53( \pm 0.15)$ & Chis work with seeds \\
\hline
\end{tabular}

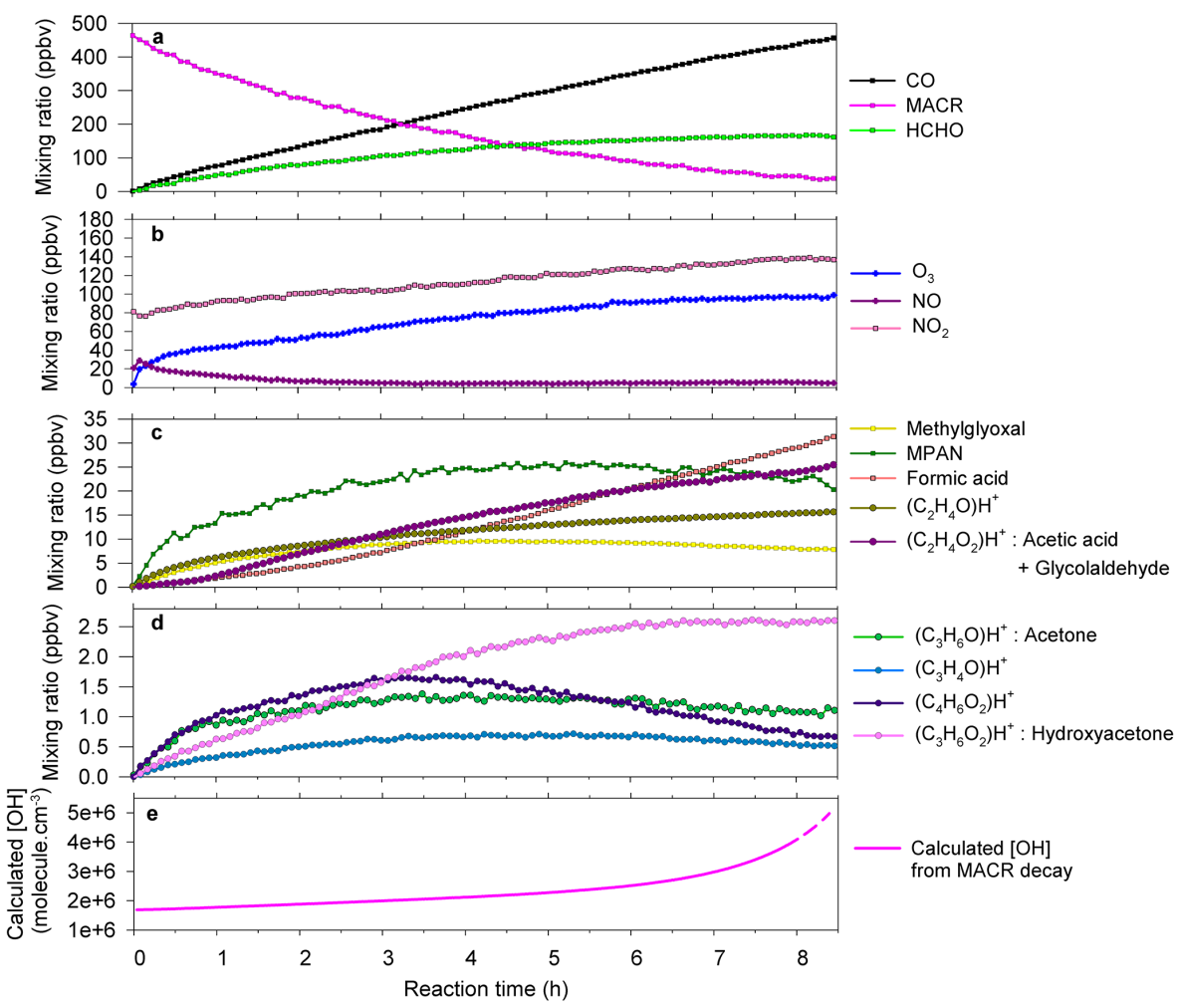

Figure 5. Time profiles of gas-phase measured compounds during MACR photooxidation (experiment M240512) performed without seed particles and with $\mathrm{NO}_{\mathrm{x}}$ as $\mathrm{OH}$ source. PTR-ToF-MS measurements are represented by circles, and FTIR measurements, by squares. Calculated $[\mathrm{OH}]$ is represented by a dotted line after $8 \mathrm{~h}$ of irradiation due to low MACR mixing ratios which implies less precision in the calculation as the contribution from other VOCs is not negligible.

its production period (i.e., after $6 \mathrm{~h}$ of reaction in Fig. $5 \mathrm{~d}$ ). The $\left(\mathrm{C}_{2} \mathrm{H}_{4} \mathrm{O}\right) \mathrm{H}^{+}$signal at $m / z, 45$ measured by PTR-ToFMS showed a primary production (Fig. $5 \mathrm{c}$ ), it was attributed to acetaldehyde with a yield of $2-6 \%$. The origin of this primary behavior is difficult to explain since it implies an $\mathrm{H}$ transfer which is complicated in gas chemistry (Fig. S5). The presence of fragments of higher molecules contributing to this signal (like methylglyoxal; Müller et al., 2012) cannot be excluded. Unfortunately, the presence of acetaldehyde in the chamber could not be verified by FTIR measurements since the maximum concentrations observed throughout all experiments were below its detection limit (i.e., $20 \mathrm{ppb}$ ). Furthermore, a release from the walls is unlikely since acetaldehyde was not observed in control experiments (i.e., irradiation of a $\mathrm{N}_{2} / \mathrm{O}_{2}$ mixture $\left.(80 / 20 \%)\right)$. 
Table 4. Yields of first-generation oxidation products during methacrolein photooxidation compared with previous studies.

\begin{tabular}{lll}
\hline Compound & Yield* & Reference \\
\hline Formaldehyde & $0.3-0.6$ & $\begin{array}{l}\text { This work } \\
\text { Orlando et al. (1999) }\end{array}$ \\
\hline \multirow{3}{*}{ Methylglyoxal } & $0.4-0.7$ & This work \\
& $<0.12$ & $\begin{array}{l}\text { Orlando et al. (1999) } \\
\text { Tuazon and Atkinson }\end{array}$ \\
& $0.08(0.004)$ & Galloway et al. (2011) \\
\hline & $0.01-0.1$ & This work \\
Hydroxyacetone & $0.41(0.03)$ & $\begin{array}{l}\text { Tuazon and Atkinson } \\
\text { (1990b) }\end{array}$ \\
& $0.47(0.05)$ & Orlando et al. (1999) \\
& $0.39(0.017)$ & Galloway et al. (2011) \\
\hline \multirow{3}{*}{ Carbon monoxide } & $0.51(0.04)$ & This work \\
& $0.45-0.85$ & Tuazon and Atkinson \\
& $0.6-0.8$ & Orlando et al. (1999) \\
\hline MPAN & $0.06-0.17$ & This work \\
& $0.04-0.30$ & Orlando et al. (1999) \\
\hline
\end{tabular}

* The range of primary yield values from this work was partially caused by the variability in the initial $\mathrm{NO}_{\mathrm{x}}$ levels.

\subsubsection{MACR-SOA yields}

SOA formation from MACR photooxidation was usually observed between $10 \mathrm{~min}$ and $1 \mathrm{~h}$ after the start of irradiation, depending on the OH level in the system. Since SOA production in these experiments began earlier than in isoprene experiments (less than $25 \%$ of MACR was consumed before the start of the SOA formation), MACR can be considered as a more direct SOA precursor (compare Fig. 6a with 2a). In all experiments, SOA mass concentration reached a plateau between 5 and $8 \mathrm{~h}$ after the onset of irradiation. These mass concentrations were calculated using an effective density of $1.4 \mathrm{~g} \mathrm{~cm}^{-3}$ which was obtained from the comparison of the mobility diameter and the vacuum aerodynamic diameter (Bahreini et al., 2005). Table 1 shows that our SOA mass yields varied between 0.6 and $4 \%$, thus 4 to 6 times higher than in isoprene experiments. Except for experiment $\mathrm{M} 250113$, the use of $\mathrm{HONO}$ as $\mathrm{OH}$ precursor led to higher yields (at least twice higher) than in experiments using $\mathrm{NO}_{\mathrm{x}}$ as $\mathrm{OH}$ source. This observation is directly linked to higher $\mathrm{OH}$ concentrations obtained at the beginning of the experiment when HONO was used (Fig. S6). Table 1 shows that the cleanliness of the walls did not affect the MACR-SOA mass yields, as opposed to isoprene experiments. It seems to suggest that the state of cleanliness of the walls would have a smaller impact on SOA yields when more direct SOA precursors are used: the extent of semi-volatile wall losses could be limited by the fast SOA production. The use of in-

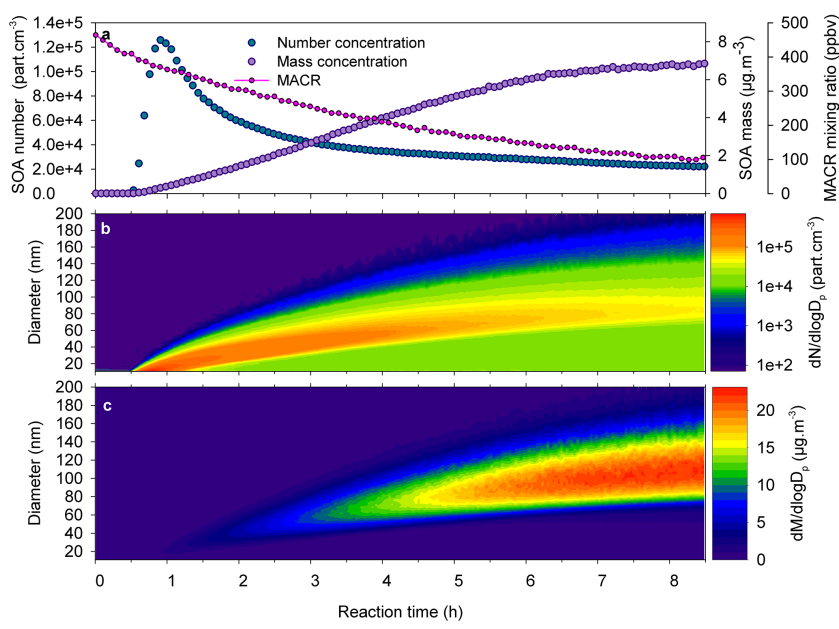

Figure 6. Time profiles of measured (a) SOA mass and number concentrations, (b) number size distribution and (c) mass size distribution during MACR photooxidation (experiment M240512) performed without seed particles and with $\mathrm{NO}_{\mathrm{x}}$ as $\mathrm{OH}$ source. A particle density of $1.4 \mathrm{~g} \mathrm{~cm}^{-3}$ was assumed (see text).

organic seed particles did not affect our SOA mass yields. Except for M240512 and M250512, initial $\mathrm{NO}_{2} / \mathrm{NO}$ ratios were below 1 , so these ratios are probably too low to make any conclusion about the influence of this ratio on SOA mass yields (Chan et al., 2010). At the end of MACR experiments, we observed particles with higher size than in isoprene experiments (compare Fig. $6 a$, c with $2 b$, c) with mean mass diameters ranging between $100 \mathrm{~nm}$ and $180 \mathrm{~nm}$.

Figure 7 shows a comparison of our MACR-SOA mass yields and the corresponding two products yield curves with the literature. For this comparison, fewer studies than for isoprene experiments are available, but it can be seen that, for MACR experiments too, SOA yields exhibit a fairly large variation. In their study, Chan et al. (2010) used two different $\mathrm{OH}$ sources (leading to a change in initial $\mathrm{NO}_{2} / \mathrm{NO}$ ratio) that affect SOA yields, resulting in two different yield curves. In our experiments, considering the differences observed between yields obtained with the two $\mathrm{OH}$ sources (which lead to similar initial $\mathrm{NO}_{2}$ / $\mathrm{NO}$ ratio), two yield curves were also modeled. Like for isoprene experiments, our SOA yields are among the lowest values from the literature, i.e., comparable to those obtained by Zhang et al. (2012) in which an outdoor chamber was used (with $\mathrm{NO}_{\mathrm{x}}$ as $\mathrm{OH}$ source), thus strengthening the hypothesis of an impact of light sources used on SOA yields. 


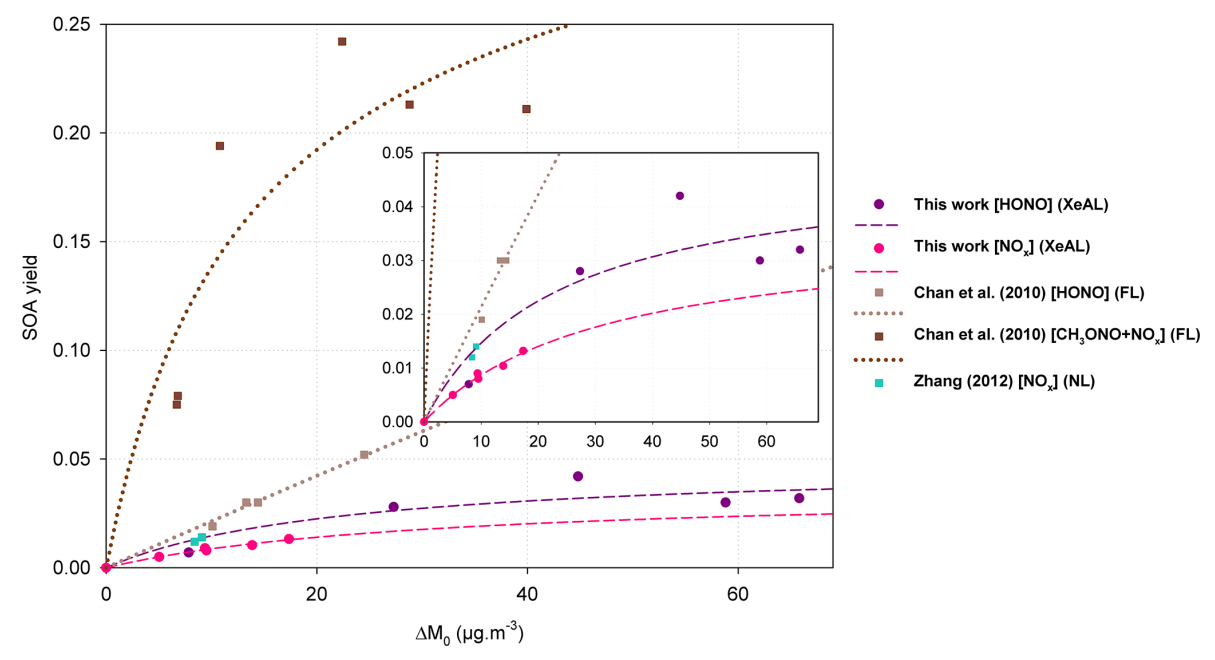

Figure 7. SOA mass yield curves from MACR photooxidation experiments in the presence of $\mathrm{NO}_{\mathrm{x}}$ carried out by Chan et al. (2010) and Zhang et al. (2012) compared with the present study. An effective density of $1.4 \mathrm{~g} \mathrm{~cm}^{-3}$ was used for conversion to mass of all our volumebased measurements. Molecules in square brackets are $\mathrm{OH}$ sources used. Light sources used are specified in parentheses (XeAL: xenon arc lamps; FL: fluorescent lamps; NL: natural light). The parameters determined for the two products model (Odum et al., 1996) in our study are, for experiments with $\mathrm{NO}_{\mathrm{x}}$ as $\mathrm{OH}$ source: $\alpha_{1}=3.6 \times 10^{-2} ; K_{\mathrm{om}, 1}=3.2 \times 10^{-2} ; \alpha_{2}=2.6 \times 10^{-11} ; K_{\mathrm{om}, 2}=1.63 \times 10^{-9}$. For experiments with $\mathrm{HONO}$ as $\mathrm{OH}$ source, these parameters are: $\alpha_{1}=4.83 \times 10^{-2} ; K_{\mathrm{om}, 1}=4.35 \times 10^{-2} ; \alpha_{2}=6.2 \times 10^{-2} ; K_{\mathrm{om}, 2}=8.47 \times 10^{-10}$.

\subsubsection{Composition of MACR-SOA}

SOA mass spectrum obtained by AMS measurements (Fig. S7b) showed no significant variation over the experiment. Its comparison with the mass spectrum of SOA from isoprene photooxidation (Fig. S7a) exhibits a high degree of similarity which strongly suggests that methacrolein is a principal intermediate in SOA formation from isoprene photooxidation in our experimental conditions, as observed by previous studies performed in the presence of $\mathrm{NO}_{\mathrm{x}}$ (Kroll et al., 2006; Surratt et al., 2006). Temporal variations of elemental ratios are presented in Figure 8. Experiments carried out with seeds showed that $\mathrm{O} / \mathrm{C}$ and $\mathrm{OM} / \mathrm{OC}$ ratios increased quickly during the first hour of SOA formation and then stabilized. Obtained ratios after stabilization were reproducible and no clear influence of $\mathrm{OH}$ source or of the presence of seeds was observed. Table 3 shows that these average values are in good agreement with elemental ratios from Chhabra et al. (2011), considering measurement uncertainties given by Aiken et al. (2008). Elemental ratios for MACR-SOA were very close to those measured for isopreneSOA, confirming the role of MACR in SOA formation from isoprene photooxidation.

\section{Atmospheric implications and conclusion}

In the present study, gas-phase products and SOA formation from isoprene and MACR photooxidation were investigated in a stainless steel simulation chamber equipped with realistic artificial light sources (Fig. S1). A good agreement with
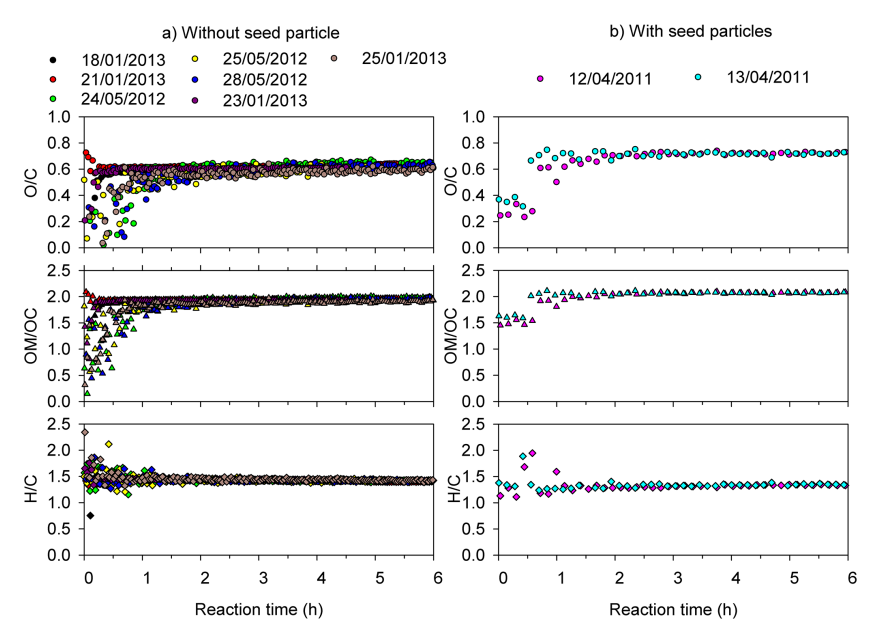

Figure 8. Time profiles of $\mathrm{O} / \mathrm{C}, \mathrm{OM} / \mathrm{OC}$ and $\mathrm{H} / \mathrm{C}$ ratios for nine different MACR photooxidation experiments performed (a) without seed particle; (b) with ammonium sulfate seed particles.

the literature was observed for the gas-phase products and particularly for primary oxidation product yields.

Comparing the SOA mass formed during isoprene experiments performed before and after manual cleaning of the chamber walls suggested an impact of the state of cleanliness of the walls on the nucleation step. While this hypothesis has not been verified with other hydrocarbons or commercially available oxidized species, it is suggested that more oxidized species could be adsorbed on clean walls, preventing the initial nucleation step. It must also be noted that such an effect has not been observed with other chemical systems (such 
as $\alpha$-pinene ozonolysis) in the same chamber (Wang et al., 2011). This may be due to the fact that the molecules produced during isoprene oxidation are much smaller and hence need to be much more oxidized to undergo partitioning; they are therefore more sensitive to wall effects. This delay in particle formation could lead to a deficit in the SOA mass because of the potentially higher proportion of isoprene oxidation products adsorbed to the clean chamber walls. Nevertheless, the partitioning of the semi-volatile compounds was reproducible within several experiments spanning over more than 3 years as shown by the high level of internal consistency of the measured data on the Odum plots (Fig. 3). Furthermore, it is striking to see that the SOA yield may vary significantly when measured in similar chambers with similar protocols (for example Kroll et al., 2005 and Dommen et al., 2006) and be in good agreement in two different chambers (Dommen et al., 2006, and this work). This somewhat contradicts the existence of a possible wall effect proposed above.

Our results for the particle phase show that SOA yields from isoprene and MACR photooxidation are in good agreement with the lowest values reported in the literature. They correspond to experiments carried out with natural irradiation or with artificial irradiation with an emission profile more similar to the solar spectrum (e.g., xenon arc lamps) than the fluorescent lamps used in other studies. It was thus suggested that the use of fluorescent lamps as irradiation sources would not activate photolysis reactions requiring longer wavelengths, such as those which break down oxidation products (e.g., methylglyoxal). These oxidation products would otherwise contribute to aerosol formation and growth, thus leading to a decrease in SOA mass yields when xenon arc lamp or natural light were used. The differences in light sources between environmental chambers may thus be able to explain partially the variability in SOA mass yield observed for identical compounds. SOA mass yields from isoprene and MACR in the atmosphere could therefore be overestimated by experiments carried out in simulation chambers equipped with fluorescent lamps. Further experiments and analysis are needed to determine the influence of the irradiation spectrum on SOA formation from isoprene and MACR photooxidation like experiments carried out by Warren et al. (2008) on the $m$-xylene/ $/ \mathrm{NO}_{\mathrm{x}}$ photooxidation system. Therefore, according to our results, isoprene and MACR SOA mass yields in the atmosphere could be lower than most current chamber studies suggest. Finally, this study highlights the need for additional work on the photochemical fate of SOA components.

\section{The Supplement related to this article is available online} at doi:10.5194/acp-15-2953-2015-supplement.
Acknowledgements. The authors are grateful to Arnaud Allanic, Pascal Renard and Pascal Zapf for their helpful contributions with handling the simulation chamber experiments. The authors gratefully acknowledge the institutions that have provided financial support: French National Institute for Geophysical Research (CNRS-INSU) within the LEFE-CHAT program through the project "Impact de la chimie des nuages sur la formation d'aérosols organiques secondaires dans l'atmosphère" and the French National Agency for Research (ANR) project CUMULUS ANR2010-BLAN-617-01. This work was also supported by the EC within the I3 project "Integrating of European Simulation Chambers for Investigating Atmospheric Processes" (EUROCHAMP-2, contract no. 228335). The authors gratefully acknowledge the MASSALYA instrumental platform (Aix Marseille Université, http://lce.univ-amu.fr) for the analysis and measurements used in this publication. We thank Clare Fitzgerald and Brendan Mahon (University of Cambridge, UK) for helpful revision of the manuscript.

Edited by: H. Saathoff

\section{References}

Aiken, A. C., DeCarlo, P. F., and Jimenez, J. L.: Elemental analysis of organic species with electron ionization high-resolution mass spectrometry, Anal. Chem., 79, 8350-8358, 2007.

Aiken, A. C., Decarlo, P. F., Kroll, J. H., Worsnop, D. R., Huffman, J. A., Docherty, K. S., Ulbrich, I. M., Mohr, C., Kimmel, J. R., Sueper, D., Sun, Y., Zhang, Q., Trimborn, A., Northway, M., Ziemann, P. J., Canagaratna, M. R., Onasch, T. B., Alfarra, M. R., Prevot, A. S. H., Dommen, J., Duplissy, J., Metzger, A., Baltensperger, U., and Jimenez, J. L.: O / C and OM / OC ratios of primary, secondary, and ambient organic aerosols with high-resolution time-of-flight aerosol mass spectrometry, Environ. Sci. Technol., 42, 4478-4485, 2008.

Atkinson, R., Baulch, D. L., Cox, R. A., Crowley, J. N., Hampson, R. F., Hynes, R. G., Jenkin, M. E., Rossi, M. J., Troe, J., and IUPAC Subcommittee: Evaluated kinetic and photochemical data for atmospheric chemistry: Volume II - gas phase reactions of organic species, Atmos. Chem. Phys., 6, 3625-4055, doi:10.5194/acp-6-3625-2006, 2006.

Bahreini, R., Keywood, M. D., Ng, N. L., Varutbangkul, V., Gao, S., Flagan, R. C., Seinfeld, J. H., Worsnop, D. R., and Jimenez, J. L.: Measurements of secondary organic aerosol from oxidation of cycloalkenes, terpenes, and m-xylene using an Aerodyne aerosol mass spectrometer, Environ. Sci. Technol., 39, 5674-5688, 2005.

Biesenthal, T. A., Wu, Q., Shepson, P. B., Wiebe, H. A., Anlauf, K. G., and Mackay, G. I.: A study of relationships between isoprene, its oxidation products, and ozone, in the Lower Fraser Valley, BC, Atmos. Environ., 31, 2049-2058, 1997.

Boge, O., Miao, Y., Plewka, A., and Herrmann, H.: Formation of secondary organic particle phase compounds from isoprene gasphase oxidation products: An aerosol chamber and field study, Atmos. Environ., 40, 2501-2509, 2006.

Canagaratna, M. R., Jayne, J. T., Jimenez, J. L., Allan, J. D., Alfarra, M. R., Zhang, Q., Onasch, T. B., Drewnick, F., Coe, H., Middlebrook, A., Delia, A., Williams, L. R., Trimborn, A. M., Northway, M. J., DeCarlo, P. F., Kolb, C. E., Davidovits, P., and 
Worsnop, D. R.: Chemical and microphysical characterization of ambient aerosols with the aerodyne aerosol mass spectrometer, Mass Spectrom. Rev., 26, 185-222, 2007.

Carlton, A. G., Wiedinmyer, C., and Kroll, J. H.: A review of Secondary Organic Aerosol (SOA) formation from isoprene, Atmos. Chem. Phys., 9, 4987-5005, doi:10.5194/acp-9-4987-2009, 2009.

Carter, W. P. L., Luo, D., Malkina, I. L., and Pierce, J. A.: Chamber Studies of Atmospheric Reactivities of Volatile Organic Compounds. Effects of Varying Chamber and Light Source, Final report to National Renewable Energy Laboratory, Coordinating Research Council, Inc., California Air Resources Board, South Coast Air Quality Management District, available at: http:// www.cert.ucr.edu/ carter/pubs/explrept.pdf (last access: 20 July 2014), 1995.

Chan, A. W. H., Chan, M. N., Surratt, J. D., Chhabra, P. S., Loza, C. L., Crounse, J. D., Yee, L. D., Flagan, R. C., Wennberg, P. O., and Seinfeld, J. H.: Role of aldehyde chemistry and $\mathrm{NO}_{\mathrm{x}}$ concentrations in secondary organic aerosol formation, Atmos. Chem. Phys., 10, 7169-7188, doi:10.5194/acp-10-7169-2010, 2010.

Chhabra, P. S., Flagan, R. C., and Seinfeld, J. H.: Elemental analysis of chamber organic aerosol using an aerodyne high-resolution aerosol mass spectrometer, Atmos. Chem. Phys., 10, 4111-4131, doi:10.5194/acp-10-4111-2010, 2010.

Chhabra, P. S., Ng, N. L., Canagaratna, M. R., Corrigan, A. L., Russell, L. M., Worsnop, D. R., Flagan, R. C., and Seinfeld, J. H.: Elemental composition and oxidation of chamber organic aerosol, Atmos. Chem. Phys., 11, 8827-8845, doi:10.5194/acp-11-88272011, 2011.

Claeys, M., Graham, B., Vas, G., Wang, W., Vermeylen, R., Pashynska, V., Cafmeyer, J., Guyon, P., Andreae, M. O., Artaxo, P., and Maenhaut, W.: Formation of secondary organic aerosols through photooxidation of isoprene, Science, 303, 1173-1176, 2004.

De Carlo, P. F., Kimmel, J. R., Trimborn, A., Northway, M. J., Jayne, J. T., Aiken, A. C., Gonin, M., Fuhrer, K., Horvath, T., Docherty, K. S., Worsnop, D. R., and Jimenez, J. L.: Field-Deployable, High-Resolution, Time-of-Flight Aerosol Mass Spectrometer, Anal. Chem., 78, 8281-8289, 2006.

Dommen, J., Metzger, A., Duplissy, J., Kalberer, M., Alfarra, M. R., Gascho, A., Weingartner, E., Prevot, A. S. H., Verheggen, B., and Baltensperger, U.: Laboratory observation of oligomers in the aerosol from isoprene/ $\mathrm{NO}_{\mathrm{x}}$ photooxidation, Geophys. Res. Lett., 33, L13805, doi:10.1029/2006GL026523, 2006.

Dunlea, E. J., Herndon, S. C., Nelson, D. D., Volkamer, R. M., San Martini, F., Sheehy, P. M., Zahniser, M. S., Shorter, J. H., Wormhoudt, J. C., Lamb, B. K., Allwine, E. J., Gaffney, J. S., Marley, N. A., Grutter, M., Marquez, C., Blanco, S., Cardenas, B., Retama, A., Ramos Villegas, C. R., Kolb, C. E., Molina, L. T., and Molina, M. J.: Evaluation of nitrogen dioxide chemiluminescence monitors in a polluted urban environment, Atmos. Chem. Phys., 7, 2691-2704, doi:10.5194/acp-7-2691-2007, 2007.

Edney, E. O., Kleindienst, T. E., Jaoui, M., Lewandowski, M., Offenberg, J. H., Wang, W., and Claeys, M.: Formation of 2-methyl tetrols and 2-methylglyceric acid in secondary organic aerosol from laboratory irradiated isoprene $/ \mathrm{NO}_{\mathrm{x}} / \mathrm{SO}_{2}$ /air mixtures and their detection in ambient PM2.5 samples collected in the eastern United States, Atmos. Environ., 39, 5281-5289, 2005.

Galloway, M. M., Huisman, A. J., Yee, L. D., Chan, A. W. H., Loza, C. L., Seinfeld, J. H., and Keutsch, F. N.: Yields of oxidized volatile organic compounds during the $\mathrm{OH}$ radical initiated oxidation of isoprene, methyl vinyl ketone, and methacrolein under high-NO $\mathrm{NO}_{\mathrm{x}}$ conditions, Atmos. Chem. Phys., 11, 10779-10790, doi:10.5194/acp-11-10779-2011, 2011.

Guenther, A., Karl, T., Harley, P., Wiedinmyer, C., Palmer, P. I., and Geron, C.: Estimates of global terrestrial isoprene emissions using MEGAN (Model of Emissions of Gases and Aerosols from Nature), Atmos. Chem. Phys., 6, 3181-3210, doi:10.5194/acp-63181-2006, 2006.

Hansel, A. and Wisthaler, A.: A method for real-time detection of PAN, PPN and MPAN in ambient air, Geophys. Res. Lett., 27, 895-898, 2000.

Healy, R. M., Wenger, J. C., Metzger, A., Duplissy, J., Kalberer, M., and Dommen, J.: Gas/particle partitioning of carbonyls in the photooxidation of isoprene and 1,3,5-trimethylbenzene, Atmos. Chem. Phys., 8, 3215-3230, doi:10.5194/acp-8-3215-2008, 2008.

Ion, A. C., Vermeylen, R., Kourtchev, I., Cafmeyer, J., Chi, X., Gelencsér, A., Maenhaut, W., and Claeys, M.: Polar organic compounds in rural $\mathrm{PM}_{2.5}$ aerosols from K-puszta, Hungary, during a 2003 summer field campaign: Sources and diel variations, Atmos. Chem. Phys., 5, 1805-1814, doi:10.5194/acp-5-1805-2005, 2005.

Kanakidou, M., Seinfeld, J. H., Pandis, S. N., Barnes, I., Dentener, F. J., Facchini, M. C., Van Dingenen, R., Ervens, B., Nenes, A., Nielsen, C. J., Swietlicki, E., Putaud, J. P., Balkanski, Y., Fuzzi, S., Horth, J., Moortgat, G. K., Winterhalter, R., Myhre, C. E. L., Tsigaridis, K., Vignati, E., Stephanou, E. G., and Wilson, J.: Organic aerosol and global climate modelling: a review, Atmos. Chem. Phys., 5, 1053-1123, doi:10.5194/acp-5-1053-2005, 2005.

Karl, M., Dorn, H. P., Holland, F., Koppmann, R., Poppe, D., Rupp, L., Schaub, A., and Wahner, A.: Product study of the reaction of $\mathrm{OH}$ radicals with isoprene in the atmosphere simulation chamber SAPHIR, J. Atmos. Chem., 55, 167-187, 2006.

Kleindienst, T. E., Edney, E. O., Lewandowski, M., Offenberg, J. H., and Jaoui, M.: Secondary organic carbon and aerosol yields from the irradiations of isoprene and alpha-pinene in the presence of $\mathrm{NO}_{\mathrm{x}}$ and $\mathrm{SO}_{2}$, Environ. Sci. Technol., 40, 3807-3812, 2006.

Kourtchev, I., Ruuskanen, T., Maenhaut, W., Kulmala, M., and Claeys, M.: Observation of 2-methyltetrols and related photo-oxidation products of isoprene in boreal forest aerosols from Hyytiälä, Finland, Atmos. Chem. Phys., 5, 2761-2770, doi:10.5194/acp-5-2761-2005, 2005.

Kroll, J. H., Ng, N. L., Murphy, S. M., Flagan, R. C., and Seinfeld, J. H.: Secondary organic aerosol formation from isoprene photooxidation under high-NOx conditions, Geophys. Res. Lett., 32, L18808, doi:10.1029/2005GL023637, 2005.

Kroll, J. H., Ng, N. L., Murphy, S. M., Flagan, R. C., and Seinfeld, J. H.: Secondary organic aerosol formation from isoprene photooxidation, Environ. Sci. Technol., 40, 1869-1877, 2006.

Loza, C. L., Chan, A. W. H., Galloway, M. M., Keutsch, F. N., Flagan, R. C., and Seinfeld, J. H.: Characterization of Vapor Wall Loss in Laboratory Chambers, Environ. Sci.Technol., 44, 50745078, 2010.

Matsunaga, A. and Ziemann, P. J.: Gas-Wall Partitioning of Organic Compounds in a Teflon Film Chamber and Potential Effects on Reaction Product and Aerosol Yield Measurements, Aerosol Sci. Tech., 44, 881-892, 2010. 
McMurry, P. H. and Rader, D. J.: Aerosol Wall Losses in Electrically Charged Chambers, Aerosol Sci. Tech., 4, 249-268, 1985.

Miyoshi, A., Hatakeyama, S., and Washida, N.: OH radical-initiated photooxidation of isoprene: an estimate of global CO production, J. Geophys. Res.-Atmos., 99, 18779-18787, 1994.

Müller, M., Graus, M., Wisthaler, A., Hansel, A., Metzger, A., Dommen, J., and Baltensperger, U.: Analysis of high mass resolution PTR-TOF mass spectra from 1,3,5-trimethylbenzene (TMB) environmental chamber experiments, Atmos. Chem. Phys., 12, 829-843, doi:10.5194/acp-12-829-2012, 2012.

Ng, N. L., Kroll, J. H., Keywood, M. D., Bahreini, R., Varutbangkul, V., Flagan, R. C., Seinfeld, J. H., Lee, A., and Goldstein, A. H.: Contribution of first- versus second-generation products to secondary organic aerosols formed in the oxidation of biogenic hydrocarbons, Environ. Sci. Technol., 40, 2283-2297, 2006.

Nguyen, T. B., Laskin, J., Laskin, A., and Nizkorodov, S. A.: Nitrogen-Containing Organic Compounds and Oligomers in Secondary Organic Aerosol Formed by Photooxidation of Isoprene, Environ. Sci. Technol., 45, 6908-6918, 2011a.

Nguyen, T. B., Roach, P. J., Laskin, J., Laskin, A., and Nizkorodov, S. A.: Effect of humidity on the composition of isoprene photooxidation secondary organic aerosol, Atmos. Chem. Phys., 11, 6931-6944, doi:10.5194/acp-11-6931-2011, 2011 b.

Odum, J. R., Hoffmann, T., Bowman, F., Collins, D., Flagan, R. C., and Seinfeld, J. H.: Gas/Particle Partitioning and Secondary Organic Aerosol Yields, Environ. Sci. Technol., 30, 2580-2585, 1996.

Orlando, J. J., Tyndall, G. S., and Paulson, S. E.: Mechanism of the $\mathrm{OH}$-initiated oxidation of methacrolein, Geophys. Res. Lett., 26, 2191-2194, 1999.

Pandis, S. N., Paulson, S. E., Seinfeld, J. H., and Flagan, R. C.: Aerosol formation in the photooxidation of isoprene and $\beta$ pinene, Atmos. Environ., Part A, General Topics, 25, 997-1008, 1991.

Pankow, J. F.: An absorption model of gas/particle partitioning of organic compounds in the atmosphere, Atmos. Environ., 28, 185-188, 1994.

Paulot, F., Crounse, J. D., Kjaergaard, H. G., Kroll, J. H., Seinfeld, J. H., and Wennberg, P. O.: Isoprene photooxidation: new insights into the production of acids and organic nitrates, Atmos. Chem. Phys., 9, 1479-1501, doi:10.5194/acp-9-1479-2009, 2009.

Paulson, S. E. and Seinfeld, J. H.: Development and evaluation of a photooxidation mechanism for isoprene, J. Geophys. Res.Atmos., 97, 20703-20715, 1992.

Paulson, S. E., Flagan, R. C., and Seinfeld, J. H.: Atmospheric photooxidation of isoprene part I: The hydroxyl radical and ground state atomic oxygen reactions, Int. J. Chem. Kinet., 24, 79-101, 1992.

Saathoff, H., Naumann, K.-H., Möhler, O., Jonsson, Å. M., Hallquist, M., Kiendler-Scharr, A., Mentel, Th. F., Tillmann, R., and Schurath, U.: Temperature dependence of yields of secondary organic aerosols from the ozonolysis of $\alpha$-pinene and limonene, Atmos. Chem. Phys., 9, 1551-1577, doi:10.5194/acp-9-15512009, 2009.

Sprengnether, M., Demerjian, K. L., Donahue, N. M., and Anderson, J. G.: Product analysis of the $\mathrm{OH}$ oxidation of isoprene and 1,3-butadiene in the presence of NO, J. Geophys. Res.-Atmos., 107, ACH 8-1-ACH 8-13, doi:10.1029/2001JD000716, 2002.
Starn, T. K., Shepson, P. B., Bertman, S. B., White, J. S., Splawn, B. G., Riemer, D. D., Zika, R. G., and Olszyna, K.: Observations of isoprene chemistry and its role in ozone production at a semirural site during the 1995 Southern Oxidants Study, J. Geophys. Res.Atmos., 103, 22425-22435, 1998.

Surratt, J. D., Murphy, S. M., Kroll, J. H., Ng, N. L., Hildebrandt, L., Sorooshian, A., Szmigielski, R., Vermeylen, R., Maenhaut, W., Claeys, M., Flagan, R. C., and Seinfeld, J. H.: Chemical composition of secondary organic aerosol formed from the photooxidation of isoprene, J. Phys. Chem. A, 110, 9665-9690, 2006.

Surratt, J. D., Chan, A. W. H., Eddingsaas, N. C., Chan, M. N., Loza, C. L., Kwan, A. J., Hersey, S. P., Flagan, R. C., Wennberg, P. O., and Seinfeld, J. H.: Reactive intermediates revealed in secondary organic aerosol formation from isoprene, Proc. Natl. Acad. Sci. USA, 107, 6640-6645, 2010.

Tuazon, E. C. and Atkinson, R.: A product study of the gas-phase reaction of methyl vinyl ketone with the $\mathrm{OH}$ radical in the presence of NOx, Int. J. Chem. Kinet., 21, 1141-1152, 1989.

Tuazon, E. C. and Atkinson, R.: A product study of the gas-phase reaction of Isoprene with the $\mathrm{OH}$ radical in the presence of $\mathrm{NOx}$, Int. J. Chem. Kinet., 22, 1221-1236, 1990a.

Tuazon, E. C. and Atkinson, R.: A product study of the gas-phase reaction of Methacrolein with the $\mathrm{OH}$ radical in the presence of NOx, Int. J. Chem. Kinet., 22, 591-602, 1990b.

Wang, J., Doussin, J. F., Perrier, S., Perraudin, E., Katrib, Y., Pangui, E., and Picquet-Varrault, B.: Design of a new multi-phase experimental simulation chamber for atmospheric photosmog, aerosol and cloud chemistry research, Atmos. Meas. Tech., 4, 2465-2494, doi:10.5194/amt-4-2465-2011, 2011.

Warren, B., Song, C., and Cocker III., D. R.,: Light intensity and light source influence on secondary organic aerosol formation for the m-xylene/NOx photooxidation system, Environ. Sci. Technol., 42, 5461-5466, 2008.

Wiedinmyer, C., Friedfeld, S., Baugh, W., Greenberg, J., Guenther, A., Fraser, M., and Allen, D.: Measurement and analysis of atmospheric concentrations of isoprene and its reaction products in central Texas, Atmos. Environ., 35, 1001-1013, 2001.

Zhang, H., Surratt, J. D., Lin, Y. H., Bapat, J., and Kamens, R. M.: Effect of relative humidity on SOA formation from isoprene/NO photooxidation: enhancement of 2-methylglyceric acid and its corresponding oligoesters under dry conditions, Atmos. Chem. Phys., 11, 6411-6424, doi:10.5194/acp-11-6411-2011, 2011.

Zhang, H. F., Lin, Y. H., Zhang, Z. F., Zhang, X. L., Shaw, S. L., Knipping, E. M., Weber, R. J., Gold, A., Kamens, R. M., and Surratt, J. D.: Secondary organic aerosol formation from methacrolein photooxidation: roles of NOx level, relative humidity and aerosol acidity, Environ. Chem., 9, 247-262, 2012.

Zhang, Q., Jimenez, J. L., Canagaratna, M. R., Allan, J. D., Coe, H., Ulbrich, I., Alfarra, M. R., Takami, A., Middlebrook, A. M., Sun, Y. L., Dzepina, K., Dunlea, E., Docherty, K., DeCarlo, P. F., Salcedo, D., Onasch, T., Jayne, J. T., Miyoshi, T., Shimono, A., Hatakeyama, S., Takegawa, N., Kondo, Y., Schneider, J., Drewnick, F., Borrmann, S., Weimer, S., Demerjian, K., Williams, P., Bower, K., Bahreini, R., Cottrell, L., Griffin, R. J., Rautiainen, J., Sun, J. Y., Zhang, Y. M., and Worsnop, D. R.: Ubiquity and dominance of oxygenated species in organic aerosols in anthropogenically-influenced Northern Hemisphere midlatitudes, Geophys. Res. Lett., 34, L13801, doi:10.1029/2007GL029979, 2007. 
Zhang, X., Cappa, C. D., Jathar, S. H., McVay, R. C., Ensberg, J. J., Kleeman, M. J., and Seinfeld, J. H.: Influence of vapor wall loss in laboratory chambers on yields of secondary organic aerosol, Proc. Natl. Acad. Sci. USA, 111, 5802-5807, 2014.
Zhou, X. L., Qiao, H. C., Deng, G. H., and Civerolo, K.: A method for the measurement of atmospheric HONO based on DNPH derivatization and HPLC analysis, Environ. Sci. Technol., 33, 3672-3679, 1999. 